\title{
Effect of Increased Nitrogen Application Rates and Environment on Protein, Oil, Fatty Acids, and Minerals in Sesame (Sesamum indicum) Seed Grown under Mississippi Delta Conditions
}

\author{
Nacer Bellaloui ${ }^{*}$, Hamed K. Abbas ${ }^{2}$, M. Wayne Ebelhar ${ }^{3}$, Alemu Mengistu4, Michael J. Mulvaney ${ }^{5}$, \\ Cesare Accinelli6, W. Thomas Shier ${ }^{7}$
}

${ }^{1}$ USDA, Agricultural Research Service, Crop Genetics Research Unit, Stoneville, MS, USA

${ }^{2}$ USDA, Agricultural Research Service, Biological Control of Pests Research Unit, Stoneville, MS, USA

${ }^{3}$ Delta Research and Extension Center, Mississippi State University, Starkville, MS, USA

${ }^{4}$ USDA, Agricultural Research Service, Crop Genetics Research Unit, Jackson, TN, USA

${ }^{5}$ Agronomy Department, West Florida Research and Education Center, University of Florida, Gainesville, FL, USA

${ }^{6}$ Department of Agricultural and Food Sciences, Alma Mater Studiorum-University of Bologna, Bologna, Italy

${ }^{7}$ Department of Medicinal Chemistry, College of Pharmacy, University of Minnesota, Minneapolis, MN, USA

Email: *nacer.bellaloui@ars.usda.gov

How to cite this paper: Bellaloui, N., Abbas, H.K., Ebelhar, M.W., Mengistu, A., Mulvaney, M.J., Accinelli, C. and Shier, W.T. (2018) Effect of Increased Nitrogen Application Rates and Environment on Protein, Oil, Fatty Acids, and Minerals in Sesame (Sesamum indicum) Seed Grown under Mississippi Delta Conditions. Food and Nutrition Sciences, 9, 1112-1135. https://doi.org/10.4236/fns.2018.99081

Received: August 8, 2018

Accepted: September 27, 2018

Published: September 30, 2018

Copyright $\odot 2018$ by authors and Scientific Research Publishing Inc. This work is licensed under the Creative Commons Attribution International License (CC BY 4.0).

http://creativecommons.org/licenses/by/4.0/ (c) (i) Open Access

\begin{abstract}
Information on the effect of nitrogen fertilizer rates and environment on sesame seed composition and nutrition is scarce. The objective of this research was to investigate the effects of nitrogen fertilizer application rates on sesame seed yield, protein, oil, fatty acids, and mineral nutrition. A two-year (2014, 2015) field experiment was conducted. Nitrogen fertilizer (urea ammonium nitrate) solution (UAN, $32 \% \mathrm{~N}$ ) was applied by side dressing to four sesame varieties (S-34, S-35, S-38, S-39) at rates of 44.7, 67.2, 89.6 and $112.0 \mathrm{~kg} \cdot \mathrm{ha}^{-1}$. Rate of $44.7 \mathrm{~kg} \cdot \mathrm{ha}^{-1}$ was used as control since this rate is traditionally recommended in the region. Increasing nitrogen application rates resulted in higher protein and oleic acid contents in two varieties in 2014, and in all varieties in 2015. Increased protein and oleic acid were accompanied by lower total oil and linoleic acid. Increased nitrogen application also resulted in higher seed $\mathrm{N}, \mathrm{S}, \mathrm{B}, \mathrm{Cu}, \mathrm{Fe}$, and $\mathrm{Zn}$ in 2014 in S-34 and S-35, but either a decline or no clear change was observed in seed levels of these nutrients in S-38 and S-39. In 2015, increased nitrogen application resulted in significantly higher seed $\mathrm{N}$ in all varieties, and higher $\mathrm{S}, \mathrm{B}, \mathrm{Cu}, \mathrm{Fe}$, and $\mathrm{Zn}$ in some varieties. A significant positive correlation was observed between nitrogen application rate and yield, and with seed levels of protein, oleic, acid, N, B, Cu, Fe, and $\mathrm{Zn}$. A significant
\end{abstract}


negative correlation was observed between nitrogen application rate and seed oil and linoleic acid. Thus, increased nitrogen fertilizer application resulted in higher seed protein, oleic acid, and some mineral nutrients, but lower oil and linoleic acid. However, this effect depended on variety and environmental conditions. Because higher protein and oleic acid are desirable traits for sesame seed nutritional value and oil stability, regional breeders should select sesame varieties for efficient fertilizer response.

\section{Keywords}

Sesame Varieties, Nitrogen Application, Seed Protein and Oil, Seed Fatty Acids, Seed Mineral Nutrition

\section{Introduction}

This Sesame has been grown for thousands of years in Africa and Asia [1] [2] [3], but it is a relatively new crop in the USA. In the last ten years, production has increased in Mississippi, Texas, Oklahoma, and New Mexico. Sesame tolerates drought, poor soil, disease, and pests, especially insects. Despite of its potential suitability in the Midsouth USA, limited research has been conducted, particularly on sesame seed quality including seed protein, oil, fatty acids, and mineral nutrition.

Sesame (Sesamum indicum) is a source of high oil (50\% - 55\%) and protein (25\%) [4], carbohydrates (16\% - 18\%) [5], antioxidants [6], and contains major mineral nutrients, including $\mathrm{K}, \mathrm{P}, \mathrm{Ca}, \mathrm{Fe}, \mathrm{Zn}, \mathrm{Cu}$, and $\mathrm{B}$. Sesame contains two predominant fatty acids (oleic and linoleic acids) [7] and has many dietary and health benefits for humans [8]. Sesame seed oil is more stable compared to other oils, because it contains high levels of antioxidants, including sesamin, sesaminol, sesamol, sesamolinol, and squalene [9], and high levels of polyunsaturated fatty acids [10].

Previous research showed that seed nutrition qualities were influenced by complex genetic and environmental factors and their interactions [5] [11] [12]. Assessing sesame newly released varieties (NCRIBEN-01M, NCRIBEN-O2M and NCRIBEN-03L) and Ex-Sudan (an exotic variety from Sudan), it was found differences in seed oil (40\% - 50\%) among varieties [13]. Studying the effects of irrigation and row-spacing in sesame, it was found that oil content was significantly affected by irrigation, but not by row-spacing [14]. They also found that protein content was highly influenced by both row-spacing and irrigation. For example, row-spacing of $70 \mathrm{~cm}$ resulted in higher protein content compared with 60 and $50 \mathrm{~cm}$. Interactions between irrigation and row-spacing had significant effects on oleic and linoleic acid contents, and correlation showed an inverse relationship between oil and protein. Their findings were comparable to others [14] in that sesame seed fatty acids are influenced by agricultural practices and environmental conditions during the growing season. Evaluated of 23 acces- 
sions showed that oil content ranged between $37 \%$ - 47\%, and the main fatty acids were palmitic, steric, oleic, and linoleic acids [15]. Although the increase of sesame seed yield is still one of the major goals of breeders, research on sesame seed nutritional quality has been scarce, especially in the USA where the crop has been recently adopted.

Fertilizer application management is critical for obtaining high yield, soil sustainability, maintaining adequate plant nutrition and high seed nutritional qualities [15]. The use of nitrogen (N) fertilizer application to increase sesame yield and yield components were previously reported, but reports on the effect of $\mathrm{N}$ fertilizers, particularly, on seed fatty acid composition of sesame are still scarce [16] [17] [18] [19]. The effects of $\mathrm{N}$ fertilizer rates $\left(0,40\right.$ and $\left.80 \mathrm{~kg} \cdot \mathrm{ha}^{-1}\right)$ on sesame yield, yield components, and seed composition, including seed protein and oil, were studied and found that $80 \mathrm{~kg} \cdot \mathrm{ha}^{-1}$ gave maximum seed yield ( 0.79 tones $\mathrm{ha}^{-1}$ ) and maximum seed oil content (45.9\%) [16]. It was reported that the application of $\mathrm{N}$ fertilizers at various rates, except $90 \mathrm{~kg} \cdot \mathrm{ha}^{-1}$, resulted in reduced seed oil contents compared to the control [20]. Other studies on other species including sesame found that application of $\mathrm{N}$ fertilizers resulted in higher yield and yield components at $60 \mathrm{~kg} \mathrm{~N} \mathrm{ha}^{-1}$ [21]; at $40 \mathrm{~kg} \mathrm{~N} \mathrm{ha}^{-1}$ [22]; at $75 \mathrm{~kg} \mathrm{~N}^{-1}$ and $60 \mathrm{~kg} \mathrm{P}_{2} \mathrm{O}_{5} \mathrm{ha}^{-1}[23]$; at $60 \mathrm{~kg} \mathrm{~N}^{-1}$ and $30 \mathrm{~kg} \mathrm{P}_{2} \mathrm{O}_{5} \mathrm{ha}^{-1}$ [24]. It was found that phosphorus application at the rate of $50 \mathrm{~kg} \mathrm{P}_{2} \mathrm{O}_{5} \mathrm{ha}^{-1}$ resulted in higher seed yield, seed oil content and seed protein content [25]. Studying the effects of $\mathrm{N}$ fertilizers (rates of 0,25 , and $50 \mathrm{~kg} \mathrm{~N} \mathrm{ha}^{-1}$ ) on three sesame cultivars, it was found that the application of $\mathrm{N}$ significantly reduced saturated fatty acids (palmitic and stearic acid), but significantly increased unsaturated fatty acids (oleic and linoleic acid) [26]. Also, they found that oleic fatty acid was significantly and negatively correlated with linoleic acid $(r=-0.79)$. It was reported that, compared to the control, $\mathrm{N}$ fertilizers increased plant height (7\%), number of capsules per plant (11\%), number of seeds per capsule (3\%), 1000 seed weight (15\%) and seed oil content (16\%) [16]. Others reported that the increased application of $\mathrm{N}$ fertilizer did not affect plant height, but increased the number of branches per plant [17], although it shown that application of $\mathrm{N}$ fertilizer increased plant height and number of branches per plant in the cultivars they studied [23]. It was reported that the application of $\mathrm{N}$ increased yield components and seed yield, but did not affect oil percentage of sesame seed [25]. Also, it was indicated that different $\mathrm{N}$ fertilizer sources resulted in highest oil and protein [27] [28]. The above literature indicates that the effects of $\mathrm{N}$ fertilizers on sesame seed composition is still not completely established and further investigation is needed, and information about its effects on fatty acids is still scarce [16] [17] [18] [29]. Our results showed that increasing $\mathrm{N}$ fertilizer rates resulted in higher seed protein, oil, and some minerals in sesame. Therefore, the objective of this research was to investigate the effect of $\mathrm{N}$ fertilizer application on nutritional qualities of sesame seed (protein, oil, fatty acids, and mineral nutrition) in field experiments under conditions of the Mississippi Delta. 


\section{Materials and Methods}

\subsection{Field Management and Growth Conditions}

Field experiments were conducted in 2014 and 2015 at Mississippi State University, Delta Research and Extension Center, Stoneville $\left(33.4240^{\circ} \mathrm{N}, 90.9151^{\circ} \mathrm{W}\right)$, MS, USA, to investigate the effects of increased $\mathrm{N}$ fertilizer application rates on sesame seed yield and quality (seed protein, oil, fatty acids, and minerals) under Mississippi Delta conditions where the growing conditions are dry and hot. Four sesame varieties (S-34, S-35, S-38, and S-39) from Sesaco, Corporation, Austin, TX, were grown and supplemental $\mathrm{N}$ fertilizer applied at four rates (44.7, 67.2, 89.6 , and $112.0 \mathrm{~kg} \cdot \mathrm{ha}^{-1}$ ) as urea ammonium nitrate and applied by side dressing. The rate of $44.7 \mathrm{~kg} \cdot \mathrm{ha}^{-1}$ was considered control as is traditionally recommended in the region. All plots, including the 0 supplement control plots, received a pre-planting surface dressing of $44.7 \mathrm{~kg} \cdot \mathrm{ha}^{-1}$ of $\mathrm{N}$ as urea ammonium nitrate solution (32\% N; urea, 46-0-0), as is traditionally recommended in the Mississippi Delta. The liquid urea ammonium nitrate (UAN) was applied. The side-dressing of $\mathrm{N}$ was performed by knifing to both sides of the bed on 11 August 2014 and 12 August 2015. Planting dates were 8 July in 2014 and 14 July in 2015, and 4 row-plots $(13.7 \mathrm{~m})$ in length on $102-\mathrm{cm}$ beds using a cone planter. The plots were irrigated by furrow irrigation in both. At seed maturity and after the field dried, the center two rows of each 4-row plots were harvested with a 2-row plot combine. Mature seed samples were cleaned and analyzed for seed composition constituents (protein, oil, and fatty acids) and mineral nutrition as described below.

\subsection{Soil Nutrients Analysis}

Nutrients in soil were analyzed using inductively coupled plasma spectrometry (Thermo Jarrell-Ash Model 61E ICP and Thermo Jarrell-Ash Autosampler 300, Thermo Jarrell-Ash Corporation, Waltham, MA, USA) on $5 \mathrm{~g}$ soil: $20 \mathrm{ml}$ Mehlich-1 solution, as previously detailed elsewhere [30] [31]. Analysis of N, S, and C were conducted based the Pregl-Dumas method [32] [33] [34] using a C/N/S elemental analyzer with thermal conductivity cells (LECOCNS-2000 elemental analyzer, LECO Corporation, St. Joseph, MI, USA). Soil samples were combusted in an oxygen atmosphere at $1350^{\circ} \mathrm{C}$ to convert elemental $\mathrm{N}, \mathrm{S}$, and $\mathrm{C}$ into $\mathrm{N}_{2}, \mathrm{SO}_{2}$, and $\mathrm{CO}_{2}$ gases, and $\mathrm{N}, \mathrm{S}$, and $\mathrm{C}$ determined by the elemental analyzer as previously detailed [30] [31]. The concentration of nutrients in random soil samples from control plots showed no soil nutrient deficiencies and no nutrients deficiencies were evident in the crop. The averages of nutrient concentrations were as follows: $\mathrm{C}=0.9 \%-1.3 \%, \mathrm{~N}=0.09 \%-0.14 \%$; and $\left(\mathrm{g} \cdot \mathrm{kg}^{-1}\right) \mathrm{P}=0.37-0.47$, $\mathrm{K}=2.1-3.1, \mathrm{~S}=0.09-0.13, \mathrm{Ca}=2.5-4.0, \mathrm{Mg}=2.7-3.4$, and $\mathrm{Fe}=14.6-27.2$; and $\left(\mathrm{mg} \cdot \mathrm{kg}^{-1}\right) \mathrm{B}=2.5-3.1, \mathrm{Cu}=8.3-15.2, \mathrm{Zn}=48.2-70.0$; and soil organic matter ranged from $2.8 \%-3.5 \%$.

\subsection{Analysis of Seed Minerals, N, S, and C}

Nutrient content in seeds was determined in ground, dried samples. Samples 
were ground with a Laboratory Mill 3600 (Perten, Springfield, IL, USA) and analyzed by digesting a $0.6 \mathrm{~g}$ in $\mathrm{HNO}_{3}$ in a microwave digestion system and nutrients were quantified using inductively coupled plasma spectrometry (Thermo Jarrell-Ash Model 61E ICP and Thermo Jarrell-Ash Autosampler 300) [30] [31]. Seed N, C, and S were determined on $0.25 \mathrm{~g}$ samples by the C/N/S elemental analyzer [30] [31].

\subsection{Determination of Seed B, Fe, and P}

Boron concentration in mature sesame seeds was determined by the azomethine-H method [35] [36]. Briefly, seed samples were ground in a Laboratory Mill 3600 (Perten, Springfield, IL, USA) and a $1.0 \mathrm{~g}$ sample was combusted to ash at $500^{\circ} \mathrm{C}$ and extracted with $20 \mathrm{ml}$ of $2 \mathrm{M} \mathrm{HCl}$ at $90^{\circ} \mathrm{C}$ for $10 \mathrm{~min}$. The mixture was filtered and a $2 \mathrm{ml}$ sample added to $4 \mathrm{ml}$ of buffer solution containing $25 \%$ ammonium acetate, $1.5 \%$ EDTA, and $12.5 \%$ acetic acid. A freshly prepared solution ( $4 \mathrm{ml}$ ) of $0.45 \%$ azomethine- $\mathrm{H}$ in $1 \%$ of ascorbic acid [37] was added, and the B concentration was measured at $420 \mathrm{~nm}$ using a Beckman Coulter DU 800 spectrophotometer (Beckman Coulter, Inc., Brea, CA, USA) [31]. Iron concentration in mature seeds was determined according to the method published elsewhere [38] [39]. Briefly, Seed samples were ground in a Laboratory Mill 3600 (Perten, Springfield, IL, USA) as described above. Then, samples were digested with hydrochloric acid (109 $\mathrm{ml}$ of $3 \% \mathrm{w} / \mathrm{w})$ and extracted. The concentration of $\mathrm{Fe}$ was determined as the color complex formed when ferrous Fe reacted with 1,10-phenanthroline as described elsewhere [30] [31]. Phenanthroline reagent solution of $0.25 \%(\mathrm{w} / \mathrm{v})$ in $25 \%(\mathrm{v} / \mathrm{v})$ ethanol and quinol solution $(1 \% \mathrm{w} / \mathrm{v})$ was prepared, and the concentrations of Fe ranging from 0.0 to $4 \mu \mathrm{g} \cdot \mathrm{ml}^{-1}$ of Fe in $0.4 \mathrm{M}$ $\mathrm{HCl}$ were made for the standard curve. Iron concentration was measured by a Beckman Coulter DU 800 spectrophotometer at an absorbance of $510 \mathrm{~nm}$ as previously described [30] [31]. Phosphorus concentration in mature seeds was determined by the yellow phosphor-vanado-molybdate complex method [40], and as previously described [30] [31]. Briefly, seed samples were ground as described above, and a $2 \mathrm{~g}$ of samples was ashed at $500^{\circ} \mathrm{C}, 10 \mathrm{ml}$ of $6 \mathrm{M} \mathrm{HCl}$ were added, and then placed in a water bath at $100^{\circ} \mathrm{C}$ until the solution evaporated to dryness. The P was extracted with $2 \mathrm{ml}$ of $36 \% \mathrm{v} / \mathrm{v} \mathrm{HCl}$. A volume of $5 \mathrm{ml}$ of $5 \mathrm{M}$ $\mathrm{HCl}$ and $5 \mathrm{ml}$ of ammonium molybdate-ammonium metavanadate reagent were added to $5 \mathrm{ml}$ of the filtrate. A standard curve Measurement of $\mathrm{P}$ was performed using a Beckman Coulter DU 800 spectrophotometer at an absorbance of $400 \mathrm{~nm}$ as previously described [30] [31].

\subsection{Fatty Acid Analysis}

Fatty acids were analyzed by extracting the total lipid fraction from matured sesame seed.

Approximately $1 \mathrm{~g}$ samples of ground seeds were extracted for about 12 hours in $3 \mathrm{ml}$ of solvent (chloroform:hexane:methanol, 8:5:2 $\mathrm{v} / \mathrm{v} / \mathrm{v}$ ) in stoppered glass 
test tubes. Fatty acid methyl esters of the lipid extracts were prepared by transesterification using sodium methoxide in methanol. The samples were analyzed by gas chromatography using Varian CP-3800 (Varian Analytical Instruments, Walnut Creek, CA) equipped with GC capillary column $\left(40^{\circ} \mathrm{C}-260^{\circ} \mathrm{C}, 30 \mathrm{~m} \times\right.$ $0.25 \mathrm{~mm} \times 0.25 \mu \mathrm{m}$ ) and flame ionization detector (FID). Chromatograms were analyzed using Star Saturn Varian Workstation Software, Varian Chromatography Systems. Calibration of fatty acids were developed using authentic fatty acid methyl esters (AOCS RM-3, Matreya LLC, PC, USA). The retention times of peaks of individual fatty acids were compared with those of authentic reference standards and the area under the curve was used to calculate the percentage of individual fatty acids. Protein content was determined by measuring total nitrogen using the Kjeldahl method [41], and protein was calculated using Dumas, N $\times 6.25$ (multiplying the $\mathrm{N}$ content in seed by 6.25) [42] [43]. Oil content was measured using the Soxhlet extraction method [44]. All measurements were made based on dry matter. Fatty acids are expressed as percent of the total oil.

\subsection{Experimental Design and Statistical Analyses}

The experiment was a part of a large project to investigate the effects of variety and increased $\mathrm{N}$ application on yield, seed quality, and mycotoxin contamination (aflatoxin, fumonisin) in sesame. Here, we report the effects of $\mathrm{N}$ fertilizer on yield and seed quality (composition and nutrition). The effects of $\mathrm{N}$ fertilizer on mycotoxins in sesame varieties will be published elsewhere (Abbas et al., unpublished). The experiment was used a split-plot design in which the main plot was variety and sub-plots were $\mathrm{N}$ rates (factorial arrangement was used with variety as main plot and $\mathrm{N}$ rates as sub-plot). Six replicates were used. Year, variety, $\mathrm{N}$ rates (treatment, $\mathrm{T}$ ) were modeled as fixed effects. Replicate (Rep) within year, and treatment by replicate within year [(Rep (Year); $\mathrm{T} \times$ Rep (Year)] were considered as a random effect. Residuals of the random effect factors are shown as covariance parameters in the tables. The residuals refer to Restricted Maximum Residual Likelihood (REML) values, which reflect the total variance of the random parameters in the model. ANOVA was conducted using Proc Mixed model in SAS; means were separated using Fisher's protected least significant difference test at the $5 \%$ level of significance using SAS [45]. Correlations were conducted using Proc Corr in SAS.

\section{Results}

ANOVA indicated that the main effects of variety (Var), treatment $(\mathrm{T})(\mathrm{N}$ fertilizer application rates), and their interactions were significant for protein, oil, oleic, and linoleic acids (Table 1). There was no effect of year $(\mathrm{Y})$ for yield and protein. There were no effects of $\mathrm{Y} \times \mathrm{T}$, Var $\times \mathrm{T}$, or $\mathrm{Y} \times \operatorname{Var}$ for yield. No effects of Var or Y by T for S were observed. Significant effects of Y, Var, T, and their interactions for $\mathrm{Mg}, \mathrm{B}, \mathrm{Cu}, \mathrm{Fe}$, and $\mathrm{Zn}$ were observed. No significant effect of $\mathrm{T}$ for $\mathrm{K}$ and $\mathrm{P}$ was observed, but significant effects of other factors for $\mathrm{K}$ and $\mathrm{P}$ 
Table 1. Statistical analysis (ANOVA) of the effects of $\mathrm{N}$ fertilizer addition on sesame seed yield, seed composition, and mineral nutrition in sesame varieties grown under Mississippi Delta conditions in field experiments in Stoneville, MS in 2014 and $2015^{\mathrm{a}}$.

\begin{tabular}{|c|c|c|c|c|c|c|c|c|c|c|c|c|c|c|c|}
\hline Effect & & Yield & & Protein & & Oil & & Oleic & & Linoleic & & $\mathrm{N}$ & & $S$ & \\
\hline & $\mathrm{DF}$ & $\mathrm{F}$ & $\mathrm{P}$ & $\mathrm{F}$ & $\mathrm{P}$ & $\mathrm{F}$ & $\mathrm{P}$ & F & $\mathrm{P}$ & $\mathrm{F}$ & $\mathrm{P}$ & F & $\mathrm{P}$ & $\mathrm{F}$ & $\mathrm{P}$ \\
\hline Year $(\mathrm{Y})$ & 1 & 1.83 & NS & 1.68 & NS & 476 & $* * *$ & 531 & $* * *$ & 47.69 & $* * *$ & 558 & $* * *$ & 15.18 & $* * *$ \\
\hline Variety (Var) & 3 & 13.4 & $* * *$ & 109 & $* * *$ & 316 & $* * *$ & 47.2 & $* * *$ & 31.67 & $* * *$ & 59.53 & $* * *$ & 1.45 & NS \\
\hline Treatment $(\mathrm{T})$ & 3 & 3.08 & $* *$ & 98.15 & $* * *$ & 98.1 & $* * *$ & 41.11 & $* * *$ & 151 & $* * *$ & 99.26 & $* * *$ & 2.01 & NS \\
\hline $\mathrm{Y} \times \mathrm{Var}$ & 3 & 6.46 & $* * *$ & 21.22 & $* * *$ & 118 & $* * *$ & 9.05 & $* * *$ & 168.29 & $* * *$ & 8.8 & $* * *$ & 1.39 & NS \\
\hline $\mathrm{Y} \times \mathrm{T}$ & 3 & 2.46 & NS & 12.39 & $* * *$ & 13.9 & $* * *$ & 2.78 & $* * *$ & 72.28 & $* * *$ & 35.49 & $* * *$ & 6.55 & $* *$ \\
\hline Var $\times \mathrm{T}$ & 9 & 0.43 & NS & 16.98 & $* * *$ & 58.52 & $* * *$ & 17.28 & $* * *$ & 33.36 & $* * *$ & 12.81 & $* * *$ & 3.24 & $* * *$ \\
\hline $\mathrm{Y} \times \operatorname{Var} \times \mathrm{T}$ & 9 & 0.67 & NS & 21.55 & $* * *$ & 17.72 & $* * *$ & 12.51 & $* * *$ & 22.79 & $* * *$ & 6.57 & $* * *$ & 3.34 & $* * *$ \\
\hline \multirow[t]{2}{*}{ Residuals } & & 2.0047 & & 0.870 & & 1.848 & & 2.825 & & 1.254 & & 0.112 & & 0.010 & \\
\hline & & $\mathrm{K}$ & & $\mathrm{Mg}$ & & $\mathrm{P}$ & & B & & $\mathrm{Cu}$ & & $\mathrm{Fe}$ & & $\mathrm{Zn}$ & \\
\hline Effect & & $\mathrm{F}$ & $\mathrm{P}$ & $\mathrm{F}$ & $\mathrm{P}$ & $\mathrm{F}$ & $\mathrm{P}$ & $\mathrm{F}$ & $\mathrm{P}$ & $\mathrm{F}$ & $\mathrm{P}$ & $\mathrm{F}$ & $\mathrm{P}$ & $\mathrm{F}$ & $\mathrm{P}$ \\
\hline Year $(\mathrm{Y})$ & 1 & 138 & $* * *$ & 10.62 & ** & 199 & $* * *$ & 25.24 & $* * *$ & 1585 & $* * *$ & 45.95 & $* * *$ & 359 & $* * *$ \\
\hline Variety (Var) & 3 & 4.07 & $* *$ & 11.79 & $* * *$ & 4.07 & $* *$ & 207 & $* * *$ & 11.02 & $* * *$ & 53.06 & $* * *$ & 110 & $* * *$ \\
\hline Treatment $(\mathrm{T})$ & 3 & 0.93 & NS & 9.94 & $* * *$ & 0.91 & NS & 40.75 & $* * *$ & 53.88 & $* * *$ & 48.83 & $* * *$ & 36.07 & $* * *$ \\
\hline $\mathrm{Y} \times \mathrm{Var}$ & 3 & 9.88 & $* * *$ & 7.94 & $* * *$ & 11.68 & $* * *$ & 23.7 & $* * *$ & 15.13 & $* * *$ & 74.28 & $* * *$ & 57.17 & $* * *$ \\
\hline $\mathrm{Y} \times \mathrm{T}$ & 3 & 5.4 & $* *$ & 8.53 & $* * *$ & 3.6 & $* *$ & 19.85 & $* * *$ & 26.07 & $* * *$ & 70.82 & $* * *$ & 6.49 & $* * *$ \\
\hline $\operatorname{Var} \times \mathrm{T}$ & 9 & 15.3 & $* * *$ & 6.61 & $* * *$ & 2.44 & $* *$ & 7.1 & $* * *$ & 47.89 & $* * *$ & 41.57 & $* * *$ & 14.5 & $* * *$ \\
\hline $\mathrm{Y} \times \operatorname{Var} \times \mathrm{T}$ & 9 & 4.31 & $* * *$ & 3.84 & $* * *$ & 3.54 & $* * *$ & 41.35 & $* * *$ & 21.27 & $* * *$ & 25.42 & $* * *$ & 19.35 & $* * *$ \\
\hline Residuals & & 0.003 & & 0.002 & & 0.004 & & 1.120 & & 0.942 & & 28.043 & & 9.857 & \\
\hline
\end{tabular}

${ }^{a}$ Nitrogen fertilizer (urea ammonium nitrate) solution (UAN, 32\% N) was applied at rates 44.7 (T1), 67.2 (T2), 89.6 (T3), and 112.0 (T4) kg.ha ${ }^{-1}$, and the rate at $44.7 \mathrm{~kg} \cdot \mathrm{ha}^{-1}$ was considered control as is traditionally recommended in the region. ${ }^{*}$ Significance at $\mathrm{P} \leq 0.05 ;{ }^{* *}$ significance at $\mathrm{P} \leq 0.01$; ${ }^{* *}$ significance at $\mathrm{P}$ $\leq 0.001$.

(Table 1). Since there were interactions between $Y$, variety, and treatment for some seed composition constituents, the results were presented by each year.

\subsection{Effects of N Fertilizer Application on Sesame Seed Yield, Composition, and Mineral Nutrients}

In 2014, $\mathrm{N}$ fertilizer application resulted in higher yield in variety S-34, but in S-35, S-38, and S-39 the yield increased at N rate of $89.6 \mathrm{~kg} \cdot \mathrm{ha}^{-1}$, then decreased at the highest rate $\left(112.1 \mathrm{~kg} \cdot \mathrm{ha}^{-1}\right)$ (Table 2). Fertilizer application resulted in higher protein in S-34 (Figure 1), S-35 (Figure 2), and S-38 (Figure 3), but not in S-39 (Figure 4). Higher oleic acid was observed in S-34 and S-35, but not in S-38 and S-39 (Table 2). The increase in protein and oleic acid were accompanied by a decrease in oil and linolenic acid, except in S-39, in which oleic acid did not show an increase with $\mathrm{N}$ fertilizer application. The concentrations of $\mathrm{B}$ and $\mathrm{Cu}$ increased in S-34, S-35, but in S-38 and S-39, there were either decreases or no clear pattern of change in these nutrients. The concentrations of Fe and $\mathrm{Zn}$ increased with the increase of $\mathrm{N}$ fertilizer application rates in S-34, S-35, and 

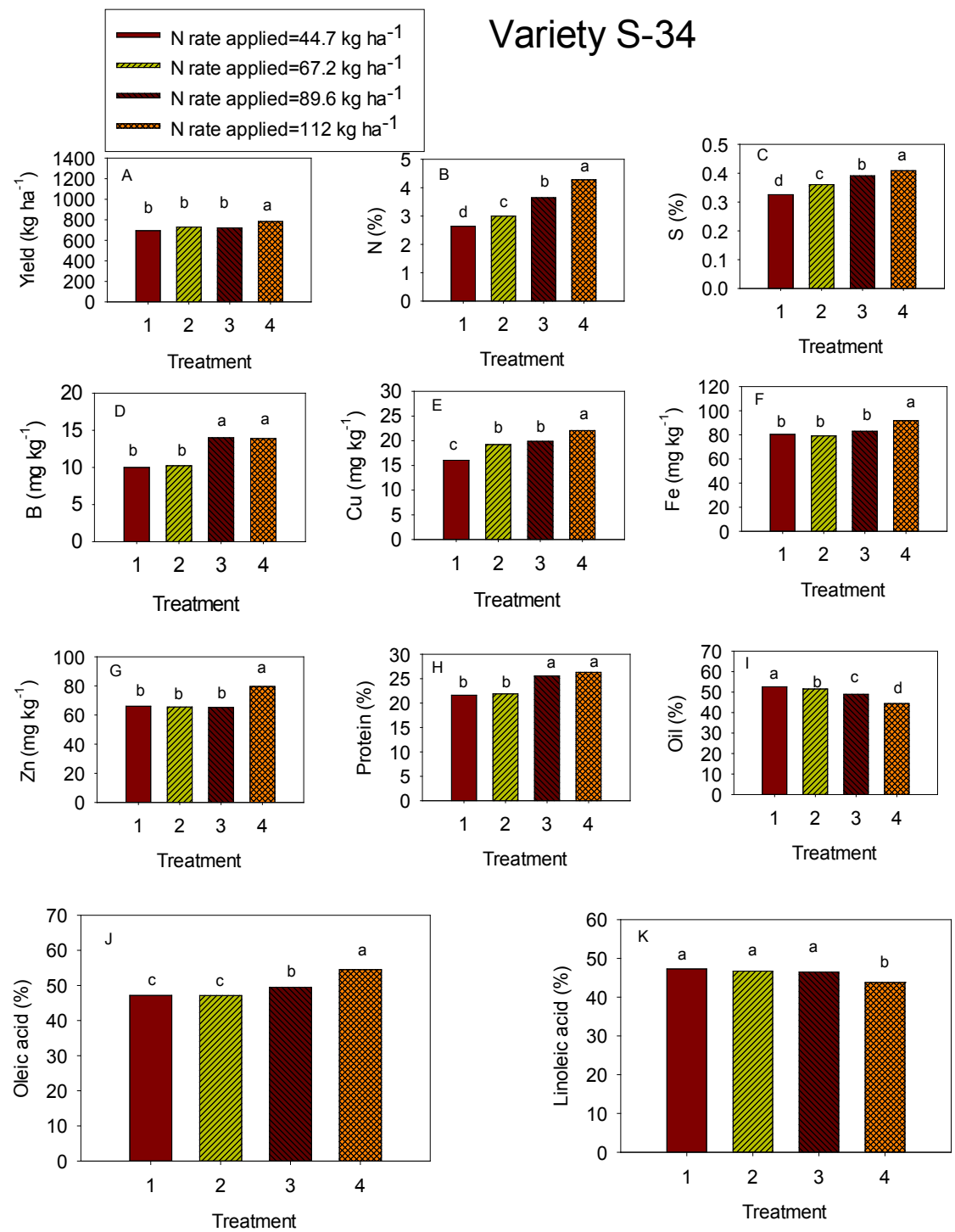

Figure 1. Effect of increased $\mathrm{N}$ fertilizer application rates $\left(\mathrm{T} 1=44.7 \mathrm{~kg} \cdot \mathrm{ha}^{-1}\right.$, control; $\mathrm{T} 2=$ $67.2 \mathrm{~kg} \cdot \mathrm{ha}^{-1}, \mathrm{~T} 3=89.6 \mathrm{~kg} \cdot \mathrm{ha}^{-1}$, and T4 $=112 \mathrm{~kg} \cdot \mathrm{ha}^{-1}$ ) on mean values of seed $\mathrm{N}, \mathrm{S}$, minerals (B, Cu, Fe, and $\mathrm{Zn}$ ), and composition constituents (protein, oil, oleic and linoleic acids) (A-K) in 2014 and 2015 in the sesame variety S-34 grown in a field experiment in Stoneville, MS under Mississippi Delta environmental and agronomic conditions. Means within bars within treatments with the same letter are not significantly different at the $5 \%$ level using Fisher's test.

S-38, but not in S-39, in which no obvious changes were observed. Nitrogen increased with fertilizer application rates in S-34 and S-35, but not in S-38 and S-39; however, $S$ increased in all varieties (Table 2, Figures 1-4).

In 2015, the application of $\mathrm{N}$ fertilizers resulted in significantly higher yield, protein, and oleic acid in all varieties (Table 3). These increases were accompanied by a decrease in oil in S-34 and S-38 only, and a decrease in linoleic acid in S-38 only. Also, increasing the $\mathrm{N}$ fertilizer addition rate led to higher seed $\mathrm{N}$ in all varieties, but $\mathrm{S}$ increased in S-39 only. Mineral concentrations increased with increasing $\mathrm{N}$ fertilizer rates. For example, B increased in S-338 and S-39; Cu in 


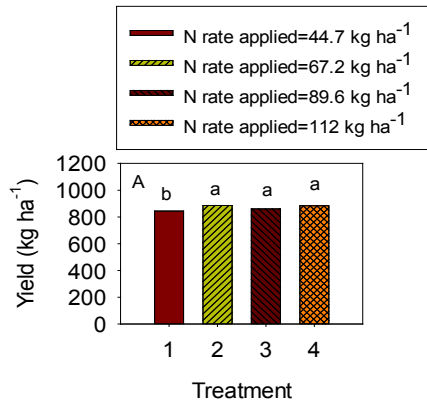

\section{Variety S-35}
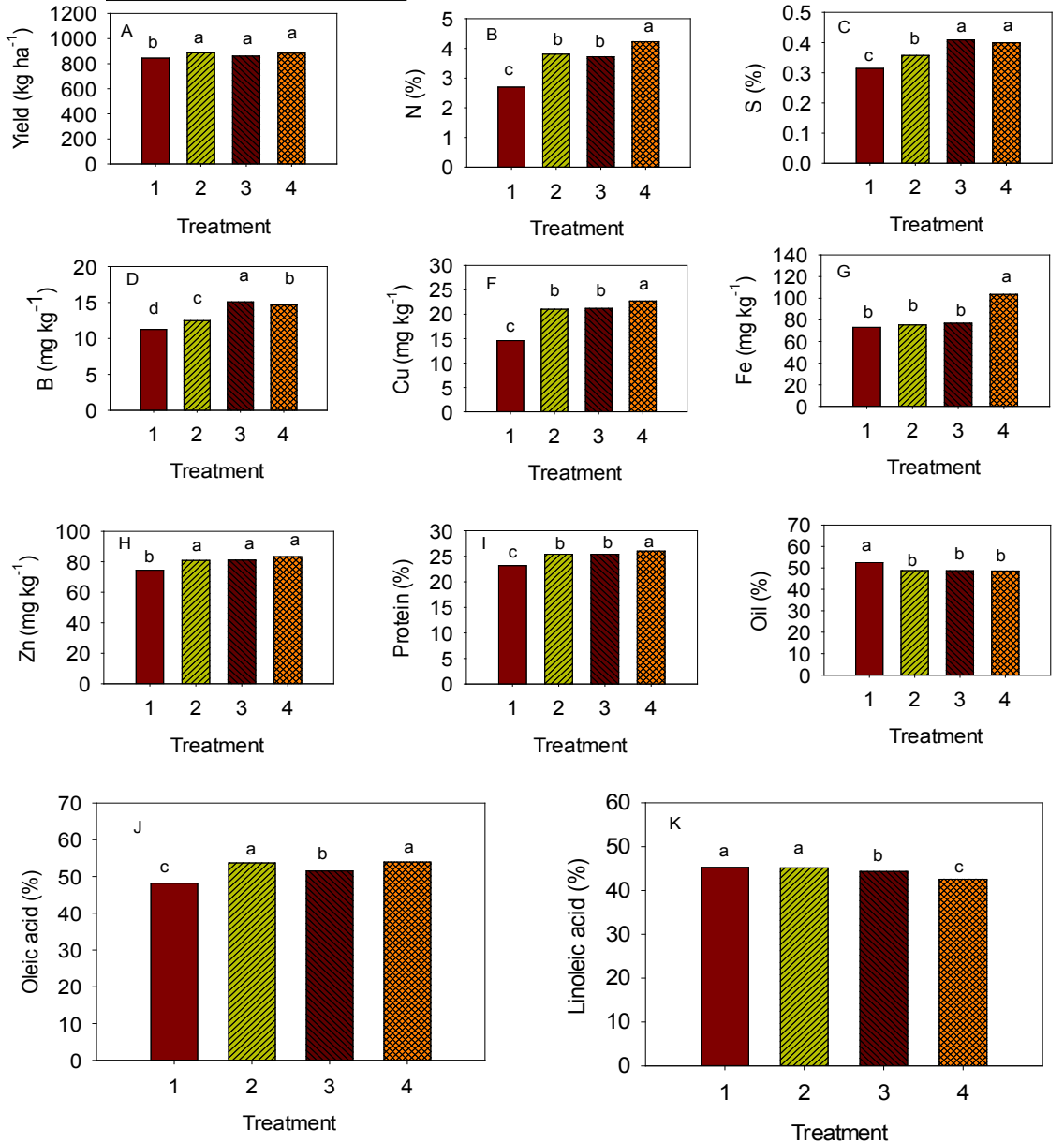

Figure 2. Effect of increased $\mathrm{N}$ fertilizer application rates $\left(\mathrm{T} 1=44.7 \mathrm{~kg} \cdot \mathrm{ha}^{-1}\right.$, control; $\mathrm{T} 2=$ $67.2 \mathrm{~kg} \cdot \mathrm{ha}^{-1}, \mathrm{~T} 3=89.6 \mathrm{~kg} \cdot \mathrm{ha}^{-1}$, and T4 $=112 \mathrm{~kg} \cdot \mathrm{ha}^{-1}$ ) on mean values of seed $\mathrm{N}, \mathrm{S}$, minerals (B, $\mathrm{Cu}, \mathrm{Fe}$, and $\mathrm{Zn}$ ), and composition constituents (protein, oil, oleic and linoleic acids) (A-K) in 2014 and 2015 in the sesame variety S-35 grown in a field experiment in Stoneville, MS under Mississippi Delta environmental and agronomic conditions. Means within bars within treatments with the same letter are not significantly different at the $5 \%$ level using Fisher's test.

Table 2. Effect of $\mathrm{N}$ fertilizer addition on sesame seed yield $\left(\mathrm{kg} \cdot \mathrm{ha}^{-1}\right)$, seed composition (\%), and nutrients ( $\mathrm{N}, \mathrm{S}, \mathrm{K}, \mathrm{Mg}$, and $\mathrm{P}$ were expressed as \%; $\mathrm{B}, \mathrm{Cu}, \mathrm{Fe}$, and $\mathrm{Zn}$ were expressed as $\mathrm{mg} \cdot \mathrm{kg}^{-1}$ ) in sesame varieties (S-34, S-35, S-38, and S-39) grown under Mississippi Delta conditions in 2014 in Stoneville, $\mathrm{MS}^{\mathrm{a}}$.

\begin{tabular}{|c|c|c|c|c|c|c|c|}
\hline & & & S-34 & 2014 & & & \\
\hline $\mathrm{N}$ rates & Yield & Protein & Oil & Oleic & Linoleic & $\mathrm{N}$ & S \\
\hline 1 & 708 & 21.00 & 51.17 & 44.50 & 48.83 & 3.18 & 0.32 \\
\hline 2 & 727 & 21.50 & 49.33 & 44.83 & 47.83 & 3.16 & 0.37 \\
\hline 3 & 734 & 27.00 & 45.33 & 48.50 & 48.17 & 4.24 & 0.42 \\
\hline 4 & 801 & 25.80 & 44.17 & 52.83 & 47.83 & 4.44 & 0.44 \\
\hline
\end{tabular}




\section{Continued}

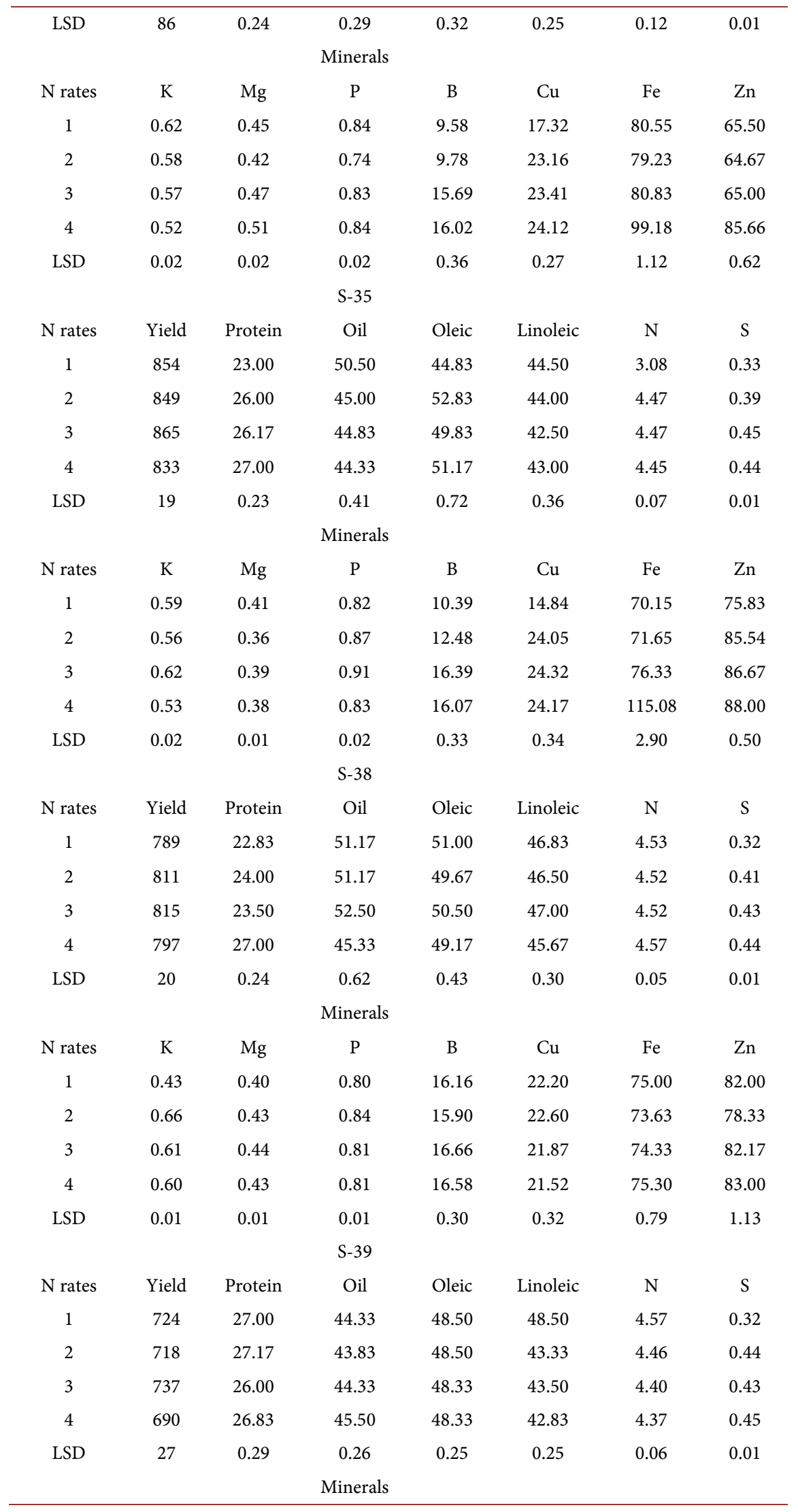




\section{Continued}

\begin{tabular}{cccccccc}
\hline N rates & $\mathrm{K}$ & $\mathrm{Mg}$ & $\mathrm{P}$ & $\mathrm{B}$ & $\mathrm{Cu}$ & $\mathrm{Fe}$ & $\mathrm{Zn}$ \\
1 & 0.58 & 0.39 & 0.84 & 17.58 & 21.87 & 74.17 & 76.17 \\
2 & 0.51 & 0.34 & 0.72 & 11.44 & 21.85 & 74.50 & 84.67 \\
3 & 0.55 & 0.49 & 0.82 & 17.08 & 22.33 & 126.00 & 83.83 \\
4 & 0.54 & 0.56 & 0.84 & 16.92 & 21.41 & 124.50 & 87.00 \\
LSD & 0.01 & 0.02 & 0.02 & 0.48 & 0.33 & 1.09 & 0.96 \\
\hline
\end{tabular}

${ }^{\mathrm{a}}$ Nitrogen fertilizer (urea ammonium nitrate) solution (UAN, 32\% N) was applied at rates 44.7 (T1), 67.2 (T2), 89.6 (T3), and 112.0 (T4) kg.ha ${ }^{-1}$, and the rate at $44.7 \mathrm{~kg} \cdot \mathrm{ha}^{-1}$ was considered control as is traditionally recommended in the region. Fisher's protected least significant difference (LSD) test at the $5 \%$ level of significance.
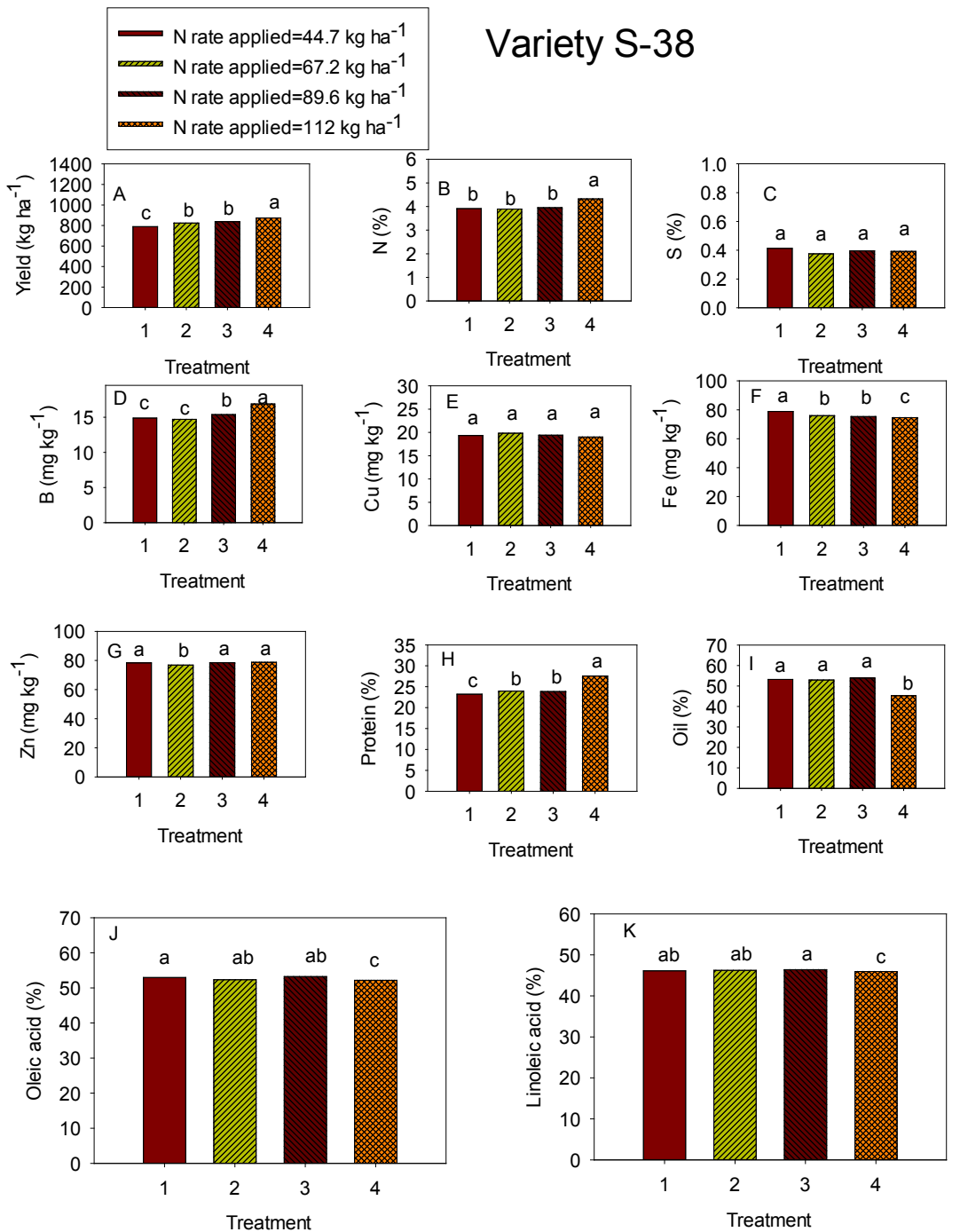

Figure 3. Effect of increased $\mathrm{N}$ fertilizer application rates $\left(\mathrm{T} 1=44.7 \mathrm{~kg} \cdot \mathrm{ha}^{-1}\right.$, control; $\mathrm{T} 2=$ $67.2 \mathrm{~kg} \cdot \mathrm{ha}^{-1}, \mathrm{~T} 3=89.6 \mathrm{~kg} \cdot \mathrm{ha}^{-1}$, and T4 $=112 \mathrm{~kg} \cdot \mathrm{ha}^{-1}$ ) on mean values of seed $\mathrm{N}, \mathrm{S}$, minerals $(\mathrm{B}, \mathrm{Cu}, \mathrm{Fe}$, and $\mathrm{Zn}$ ), and composition constituents (protein, oil, oleic and linoleic acids) (A-K) in 2014 and 2015 in the sesame variety S-38 grown in a field experiment in Stoneville, MS under Mississippi Delta environmental and agronomic conditions. Means within bars within treatments with the same letter are not significantly different at the $5 \%$ level using Fisher's test. 

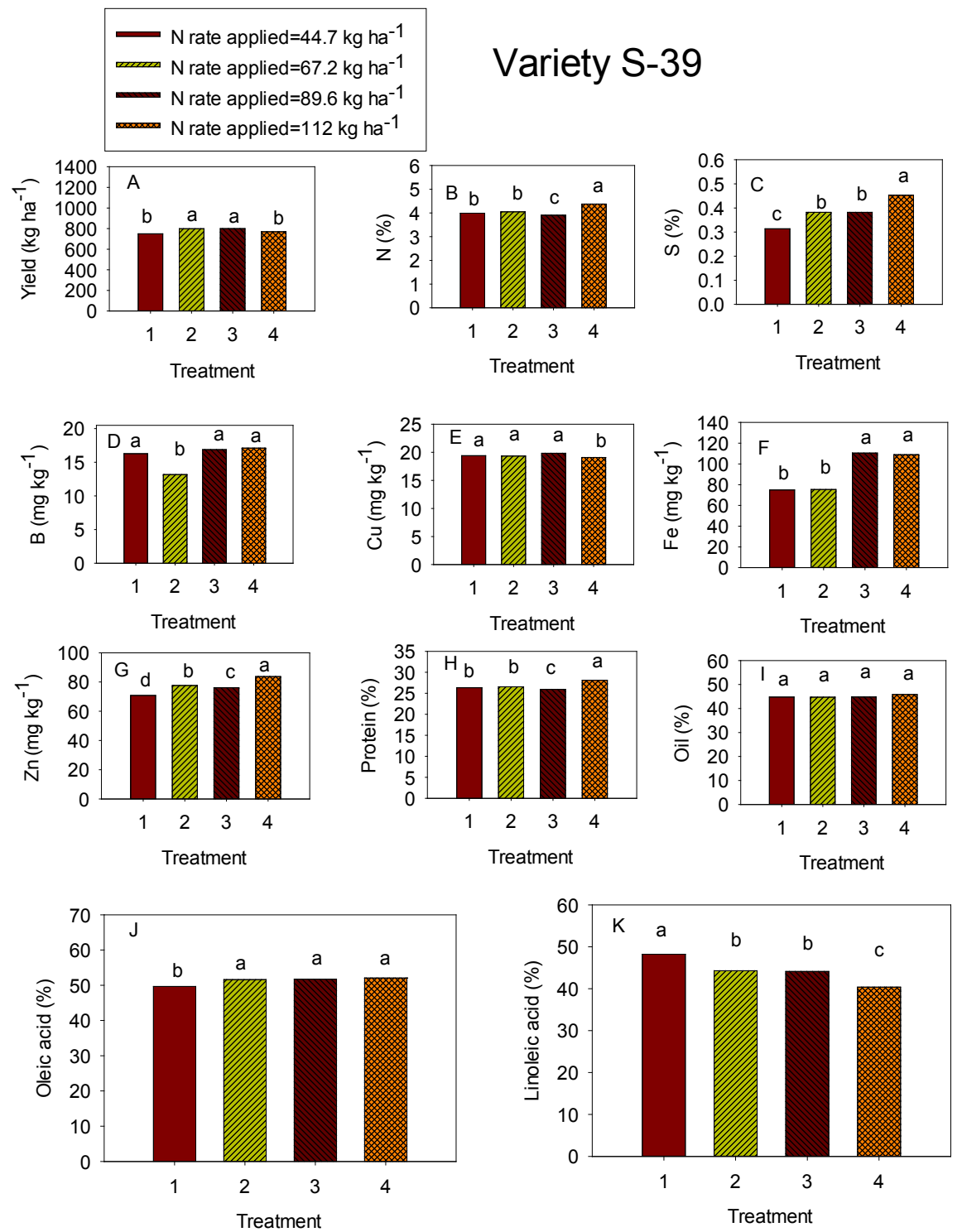

Figure 4. Effect of increased $\mathrm{N}$ fertilizer application rates $\left(\mathrm{T} 1=44.7 \mathrm{~kg} \cdot \mathrm{ha}^{-1}\right.$, control; $\mathrm{T} 2=$ $67.2 \mathrm{~kg} \cdot \mathrm{ha}^{-1}, \mathrm{~T} 3=89.6 \mathrm{~kg} \cdot \mathrm{ha}^{-1}$, and T4 $=112 \mathrm{~kg} \cdot \mathrm{ha}^{-1}$ ) on mean values of seed N, S, minerals (B, $\mathrm{Cu}, \mathrm{Fe}$, and $\mathrm{Zn}$ ), and composition constituents (protein, oil, oleic and linoleic acids) (A-K) in 2014 and 2015 in the sesame variety S-39 grown in a field experiment in Stoneville, MS under Mississippi Delta environmental and agronomic conditions. Means within bars within treatments with the same letter are not significantly different at the $5 \%$ level using Fisher's test.

S-34 and S-35, and S-38; Fe in S-35; Zn in S-35 and S-39. Increasing fertilizer rates also resulted in higher $\mathrm{K}$ in S-38 and S-39, but $\mathrm{K}$ decreased with increasing fertilizer rates in S-34 and S-35 (Table 3).

\subsection{Correlations between N Fertilizer Rates and Seed Composition and Mineral Nutrients}

In 2014, $\mathrm{N}$ fertilizer application rates (Treatment, $\mathrm{T}$ ) were found to correlate positively with protein, oleic acid, $\mathrm{Mg}, \mathrm{N}, \mathrm{S}, \mathrm{B}, \mathrm{Cu}, \mathrm{Fe}$, and $\mathrm{Zn}$ (Table 4). A negative 
Table 3. Effect of $\mathrm{N}$ fertilizer addition on sesame seed yield $\left(\mathrm{kg} \cdot \mathrm{ha}^{-1}\right)$, seed composition (\%), and nutrients ( $\mathrm{N}, \mathrm{S}, \mathrm{K}, \mathrm{Mg}$, and $\mathrm{P}$ were expressed as \%; $\mathrm{B}, \mathrm{Cu}, \mathrm{Fe}$, and $\mathrm{Zn}$ were expressed as $\mathrm{mg} \cdot \mathrm{kg}^{-1}$ ) in sesame varieties (S-34, S-35, S-38, and S-39) grown under Mississippi Delta conditions in 2015 in Stoneville, MS $^{\mathrm{a}}$.

\begin{tabular}{|c|c|c|c|c|c|c|c|}
\hline & & & S-34 & 2015 & & & \\
\hline $\mathrm{N}$ rates & Yield & Protein & Oil & Oleic & Linoleic & $\mathrm{N}$ & $S$ \\
\hline 1 & 667 & 22.83 & 55.50 & 52.50 & 44.17 & 1.57 & 0.34 \\
\hline 2 & 736 & 22.67 & 55.83 & 51.67 & 44.50 & 2.68 & 0.34 \\
\hline 3 & 696 & 22.67 & 56.00 & 51.50 & 43.17 & 2.47 & 0.33 \\
\hline 4 & 748 & 27.17 & 44.83 & 57.83 & 35.67 & 3.95 & 0.34 \\
\hline \multirow[t]{2}{*}{ LSD } & 80 & 0.49 & 0.48 & 1.19 & 0.44 & 0.17 & 0.01 \\
\hline & & & Mineral & & & & \\
\hline $\mathrm{N}$ rates & $\mathrm{K}$ & $\mathrm{Mg}$ & $\mathrm{P}$ & B & $\mathrm{Cu}$ & $\mathrm{Fe}$ & $\mathrm{Zn}$ \\
\hline 1 & 0.48 & 0.42 & 0.78 & 10.83 & 13.50 & 80.33 & 67.17 \\
\hline 2 & 0.45 & 0.39 & 0.77 & 11.17 & 12.50 & 79.17 & 67.17 \\
\hline 3 & 0.44 & 0.40 & 0.69 & 10.67 & 12.83 & 87.50 & 65.83 \\
\hline 4 & 0.42 & 0.42 & 0.71 & 9.67 & 18.00 & 77.17 & 67.67 \\
\hline \multirow[t]{2}{*}{ LSD } & 0.02 & 0.02 & 0.02 & 0.38 & 0.37 & 1.75 & 1.18 \\
\hline & & & S-35 & & & & \\
\hline $\mathrm{N}$ rates & Yield & Protein & Oil & Oleic & Linoleic & $\mathrm{N}$ & $S$ \\
\hline 1 & 826 & 23.50 & 56.50 & 54.83 & 46.83 & 1.93 & 0.29 \\
\hline 2 & 958 & 24.17 & 56.17 & 55.50 & 47.50 & 2.48 & 0.30 \\
\hline 3 & 853 & 23.83 & 56.33 & 54.83 & 48.00 & 2.23 & 0.33 \\
\hline 4 & 985 & 24.00 & 57.00 & 59.50 & 41.67 & 3.78 & 0.33 \\
\hline \multirow[t]{3}{*}{ LSD } & 64 & 0.50 & 0.56 & 0.69 & 0.76 & 0.13 & 0.02 \\
\hline & & & Mineral & & & & \\
\hline & K & $\mathrm{Mg}$ & $\mathrm{P}$ & B & $\mathrm{Cu}$ & $\mathrm{Fe}$ & $\mathrm{Zn}$ \\
\hline 1 & 0.51 & 0.39 & 0.66 & 13.00 & 14.17 & 79.17 & 71.83 \\
\hline 2 & 0.51 & 0.38 & 0.66 & 12.50 & 15.00 & 82.67 & 71.67 \\
\hline 3 & 0.52 & 0.42 & 0.64 & 12.50 & 15.00 & 78.00 & 70.17 \\
\hline 4 & 0.47 & 0.38 & 0.69 & 11.83 & 19.83 & 80.67 & 74.00 \\
\hline \multirow[t]{2}{*}{ LSD } & 0.02 & 0.01 & 0.02 & 0.43 & 0.33 & 2.31 & 1.88 \\
\hline & & & S-38 & & & & \\
\hline $\mathrm{N}$ rates & Yield & Protein & Oil & Oleic & Linoleic & $\mathrm{N}$ & $S$ \\
\hline 1 & 788 & 24.00 & 57.33 & 56.83 & 44.67 & 2.67 & 0.59 \\
\hline 2 & 851 & 23.83 & 56.50 & 57.67 & 45.67 & 2.63 & 0.30 \\
\hline 3 & 881 & 24.50 & 56.67 & 58.67 & 45.17 & 2.82 & 0.32 \\
\hline 4 & 1026 & 28.67 & 45.00 & 58.17 & 46.50 & 3.83 & 0.29 \\
\hline \multirow[t]{2}{*}{ LSD } & 43 & 0.35 & 0.56 & 0.49 & 0.39 & 0.20 & 0.14 \\
\hline & & & Mineral & & & & \\
\hline $\mathrm{N}$ rates & K & $\mathrm{Mg}$ & $\mathrm{P}$ & B & $\mathrm{Cu}$ & $\mathrm{Fe}$ & $\mathrm{Zn}$ \\
\hline 1 & 0.38 & 0.43 & 0.70 & 12.33 & 13.67 & 86.67 & 71.00 \\
\hline
\end{tabular}




\begin{tabular}{|c|c|c|c|c|c|c|c|}
\hline \multicolumn{8}{|c|}{ Continued } \\
\hline 2 & 0.45 & 0.44 & 0.70 & 12.33 & 14.33 & 80.67 & 73.83 \\
\hline 3 & 0.37 & 0.41 & 0.70 & 12.83 & 14.50 & 77.33 & 71.17 \\
\hline 4 & 0.58 & 0.40 & 0.68 & 17.50 & 14.00 & 73.33 & 70.33 \\
\hline \multirow[t]{2}{*}{ LSD } & 0.01 & 0.02 & 0.02 & 0.37 & 0.28 & 1.68 & 1.47 \\
\hline & & & S-39 & & & & \\
\hline $\mathrm{N}$ rates & Yield & Protein & Oil & Oleic & Linoleic & $\mathrm{N}$ & S \\
\hline 1 & 801 & 25.00 & 45.67 & 52.00 & 47.67 & 2.83 & 0.30 \\
\hline 2 & 963 & 25.33 & 46.50 & 57.83 & 46.17 & 3.23 & 0.27 \\
\hline 3 & 924 & 25.83 & 45.83 & 58.50 & 45.33 & 2.92 & 0.29 \\
\hline 4 & 930 & 30.67 & 46.50 & 59.50 & 35.50 & 4.38 & 0.45 \\
\hline \multirow[t]{2}{*}{ LSD } & 59 & 0.48 & 0.50 & 0.53 & 0.49 & 0.20 & 0.02 \\
\hline & & & Minerals & & & & \\
\hline $\mathrm{N}$ rates & $\mathrm{K}$ & $\mathrm{Mg}$ & $\mathrm{P}$ & B & $\mathrm{Cu}$ & $\mathrm{Fe}$ & $\mathrm{Zn}$ \\
\hline 1 & 0.49 & 0.36 & 0.70 & 13.67 & 14.50 & 76.50 & 60.00 \\
\hline 2 & 0.48 & 0.40 & 0.68 & 16.67 & 14.33 & 77.00 & 63.50 \\
\hline 3 & 0.50 & 0.40 & 0.67 & 16.50 & 14.83 & 79.50 & 60.67 \\
\hline 4 & 0.54 & 0.40 & 0.64 & 17.50 & 14.50 & 77.83 & 77.17 \\
\hline LSD & 0.02 & 0.02 & 0.02 & 0.35 & 0.46 & 1.46 & 1.98 \\
\hline
\end{tabular}

${ }^{a}$ Nitrogen fertilizer (urea ammonium nitrate) solution (UAN, 32\% N) was applied at rates 44.7 (T1), 67.2 (T2), 89.6 (T3), and 112.0 (T4) kg.ha ${ }^{-1}$, and the rate at $44.7 \mathrm{~kg} \cdot \mathrm{ha}^{-1}$ was considered control as is traditionally recommended in the region. Fisher's protected least significant difference (LSD) test at the $5 \%$ level of significance.

Table 4. Correlations ( $\mathrm{P}$ and $\mathrm{R}$ values) between seed yield and seed nutritional qualities components across $\mathrm{N}$ rates and across varieties in a field experiment grown under the Mississippi Delta conditions in Stoneville, MS in 2014a

\begin{tabular}{|c|c|c|c|c|c|c|c|c|c|c|c|c|c|c|}
\hline Variable & $\begin{array}{c}R \text { and } P \\
\text { values }\end{array}$ & yield & K & $\mathrm{Mg}$ & $\mathrm{P}$ & $\mathrm{N}$ & $S$ & B & $\mathrm{Cu}$ & $\mathrm{Fe}$ & $\mathrm{Zn}$ & Protein & Oil & Oleic \\
\hline \multirow[t]{2}{*}{ Yield } & $\mathrm{R}=\mathrm{NS}$ & & & & & & & & & & & & & \\
\hline & $\mathrm{P}=\mathrm{NS}$ & & & & & & & & & & & & & \\
\hline \multirow{2}{*}{ K } & $\mathrm{R}=\mathrm{NS}$ & NS & & & & & & & & & & & & \\
\hline & $\mathrm{P}=\mathrm{NS}$ & & & & & & & & & & & & & \\
\hline \multirow{2}{*}{$\mathrm{Mg}$} & $\mathrm{R}=0.374$ & NS & NS & & & & & & & & & & & \\
\hline & $\mathrm{P}=* * *$ & & & & & & & & & & & & & \\
\hline \multirow{2}{*}{$\mathrm{P}$} & $\mathrm{R}=\mathrm{NS}$ & NS & 0.204 & 0.145 & & & & & & & & & & \\
\hline & $\mathrm{P}=\mathrm{NS}$ & & $* *$ & ** & & & & & & & & & & \\
\hline \multirow{2}{*}{$\mathrm{N}$} & $\mathrm{R}=0.398$ & NS & -0.144 & NS & NS & & & & & & & & & \\
\hline & $\mathrm{P}=* * *$ & & * & & & & & & & & & & & \\
\hline \multirow{2}{*}{ S } & $\mathrm{R}=0.795$ & NS & NS & 0.218 & NS & 0.409 & & & & & & & & \\
\hline & $\mathrm{P}=* * *$ & & & $* *$ & & $* * *$ & & & & & & & & \\
\hline \multirow{2}{*}{ B } & $\mathrm{R}=0.475$ & NS & NS & 0.281 & 0.173 & 0.676 & 0.351 & & & & & & & \\
\hline & $\mathrm{P}=* * *$ & & & $* * *$ & * & $* * *$ & $* * *$ & & & & & & & \\
\hline $\mathrm{Cu}$ & $\mathrm{R}=0.476$ & NS & NS & NS & NS & 0.583 & 0.477 & 0.407 & & & & & & \\
\hline
\end{tabular}




\section{Continued}

\begin{tabular}{|c|c|c|c|c|c|c|c|c|c|c|c|c|c|c|}
\hline & $\mathrm{P}=* * *$ & & & & & $* * *$ & $* * *$ & $* * *$ & & & & & & \\
\hline \multirow{2}{*}{$\mathrm{Fe}$} & $\mathrm{R}=0.574$ & NS & -0.180 & 0.479 & NS & 0.142 & 0.394 & 0.300 & 0.198 & & & & & \\
\hline & $\mathrm{P}=* * *$ & & * & $* * *$ & & * & $* * *$ & $* * *$ & $* *$ & & & & & \\
\hline \multirow{2}{*}{$\mathrm{Zn}$} & $\mathrm{R}=0.459$ & NS & -0.171 & NS & NS & 0.572 & 0.453 & 0.480 & 0.333 & 0.313 & & & & \\
\hline & $\mathrm{P}=* * *$ & & 0.018 & & & $* * *$ & $* * *$ & $* * *$ & $* * *$ & $* * *$ & & & & \\
\hline \multirow{2}{*}{ Protein } & $\mathrm{R}=0.531$ & NS & NS & NS & 0.144 & 0.568 & 0.529 & 0.490 & 0.398 & 0.284 & 0.509 & & & \\
\hline & $\mathrm{P}=* * *$ & & & & * & $* * *$ & $* * *$ & $* * *$ & $* * *$ & $* * *$ & $* * *$ & & & \\
\hline \multirow{2}{*}{ Oil } & $\mathrm{R}=-0.454$ & NS & NS & NS & NS & -0.378 & -0.404 & -0.248 & -0.434 & -0.369 & -0.362 & -0.743 & & \\
\hline & $\mathrm{P}=* * *$ & & & & & $* * *$ & $* * *$ & $* * *$ & $* * *$ & $* * *$ & $* * *$ & $* * *$ & & \\
\hline \multirow{2}{*}{ Oleic } & $\mathrm{R}=0.372$ & NS & -0.239 & NS & NS & 0.625 & 0.313 & 0.487 & 0.589 & NS & 0.570 & 0.347 & -0.271 & \\
\hline & $\mathrm{P}=* * \star$ & & $* * *$ & & & $* * *$ & $* * *$ & $* * *$ & $* * *$ & & $* * *$ & $* * *$ & $* * *$ & \\
\hline \multirow{2}{*}{ Linoleic } & $\mathrm{R}=-0.330$ & NS & NS & 0.183 & NS & -0.210 & -0.415 & NS & NS & -0.345 & -0.602 & -0.404 & 0.376 & -0.174 \\
\hline & $\mathrm{P}=* * *$ & & & * & & $* *$ & $* * *$ & & & $* * *$ & $* * *$ & $* * *$ & $* * *$ & * \\
\hline
\end{tabular}

${ }^{a}$ Nitrogen fertilizer (urea ammonium nitrate) solution (UAN, 32\% N) was applied at rates 44.7 (T1), 67.2 (T2), 89.6 (T3), and 112.0 (T4) kg.ha ${ }^{-1}$, and the rate at $44.7 \mathrm{~kg} \cdot \mathrm{ha}^{-1}$ was considered control as is traditionally recommended in the region. ${ }^{\star}$ Significance at $\mathrm{P} \leq 0.05$; ${ }^{* *}$ significance at $\mathrm{P} \leq 0.01$; ${ }^{* *}$ significance at $\mathrm{P}$ $\leq 0.001$.

correlation existed between fertilizer application rates and oil and linoleic acid. A positive correlation was observed between seed $\mathrm{N}$ and the nutrients $\mathrm{S}, \mathrm{B}, \mathrm{Cu}$, $\mathrm{Fe}$, and $\mathrm{Zn}$ (Table 4). There was a positive correlation between seed protein and $\mathrm{N}, \mathrm{S}, \mathrm{B}, \mathrm{Cu}, \mathrm{Fe}$, and $\mathrm{Zn}$, and a positive correlation between oleic acid and $\mathrm{N}, \mathrm{S}, \mathrm{B}$, $\mathrm{Cu}$, and $\mathrm{Zn}$. There was a negative correlation between seed oil and seed $\mathrm{N}, \mathrm{S}, \mathrm{B}$, $\mathrm{Cu}, \mathrm{Fe}$, and $\mathrm{Zn}$. There was a negative correlation between seed linolenic acid and $\mathrm{Cu}, \mathrm{Fe}$, and $\mathrm{Zn}$. No correlation was found between seed oil and $\mathrm{K}, \mathrm{Mg}$ and $\mathrm{P}$ or between seed linoleic acid and $\mathrm{K}, \mathrm{P}, \mathrm{B}$, and $\mathrm{Cu}$ (Table 4).

In 2015, there was a positive correlation between $\mathrm{N}$ fertilizer application rates and yield (Table 5), differing from 2014 when no correlation was found. There were positive correlations between seed protein and oleic acid, N, B, Cu, and $\mathrm{Zn}$. There were no correlations between $\mathrm{N}$ fertilizer application rates and $\mathrm{Mg}, \mathrm{S}$ or $\mathrm{Fe}$, differing from 2014 (Table 5). No correlation was observed between $\mathrm{N}$ fertilizer application rates and K, as observed in 2014. Negative correlations were found between $\mathrm{N}$ fertilizer application rates and seed oil and linoleic acid, confirming the observation in 2014. A positive correlation was found between seed protein and yield, differing from 2014, and positive correlation between $\mathrm{N}$ fertilizer application rates and seed $\mathrm{N}$ and $\mathrm{B}$, confirming the similar observation in 2014. There were negative correlations between seed oil and $\mathrm{N}$ fertilizer application rates, yield, $\mathrm{K}$, and seed $\mathrm{N}$, and positive correlations between seed oil and $\mathrm{Fe}$ and $\mathrm{Zn}$. In both years, there were negative correlations between seed oil and protein, and between oleic and linoleic acid (Table 5).

\section{Discussion}

The significant effects of the main factors of Var and $\mathrm{N}$ fertilizer on seed protein, 
Table 5. Correlations ( $\mathrm{P}$ and $\mathrm{R}$ values) between seed yield and seed nutritional qualities components across $\mathrm{N}$ rates and across varieties in a field experiment grown under the Mississippi Delta conditions in Stoneville, MS in 2015 .

\begin{tabular}{|c|c|c|c|c|c|c|c|c|c|c|c|c|c|c|}
\hline Variable & $\mathrm{T}$ & Yield & K & $\mathrm{Mg}$ & $\mathrm{P}$ & $\mathrm{N}$ & S & B & $\mathrm{Cu}$ & $\mathrm{Fe}$ & $\mathrm{Zn}$ & Protein & Oil & Oleic \\
\hline \multirow[t]{3}{*}{ Yield } & $\mathrm{R}=0.260$ & & & & & & & & & & & & & \\
\hline & $\mathrm{P}=$ * & & & & & & & & & & & & & \\
\hline & $\mathrm{R}=\mathrm{NS}$ & 0.261 & & & & & & & & & & & & \\
\hline K & $\mathrm{P}=\mathrm{NS}$ & ** & & & & & & & & & & & & \\
\hline \multirow{2}{*}{$\mathrm{Mg}$} & $\mathrm{R}=\mathrm{NS}$ & NS & NS & & & & & & & & & & & \\
\hline & $\mathrm{P}=\mathrm{NS}$ & & & & & & & & & & & & & \\
\hline \multirow{2}{*}{$\mathrm{P}$} & $\mathrm{R}=-0.219$ & -0.251 & -0.317 & NS & & & & & & & & & & \\
\hline & $\mathrm{P}=$ * & ** & ** & & & & & & & & & & & \\
\hline \multirow{2}{*}{$\mathrm{N}$} & $\mathrm{R}=0.670$ & 0.330 & NS & NS & NS & & & & & & & & & \\
\hline & $\mathrm{P}=* * *$ & $* *$ & & & & & & & & & & & & \\
\hline \multirow{2}{*}{$S$} & $\mathrm{R}=\mathrm{NS}$ & NS & NS & NS & NS & NS & & & & & & & & \\
\hline & $\mathrm{P}=\mathrm{NS}$ & & & & & & & & & & & & & \\
\hline \multirow{2}{*}{ B } & $\mathrm{R}=0.216$ & 0.391 & 0.505 & NS & -0.387 & 0.363 & NS & & & & & & & \\
\hline & $\mathrm{P}=$ * & $* * *$ & $* * *$ & & $* * *$ & $* * *$ & & & & & & & & \\
\hline \multirow{2}{*}{$\mathrm{Cu}$} & $\mathrm{R}=0.466$ & NS & NS & NS & NS & 0.396 & NS & NS & & & & & & \\
\hline & $\mathrm{P}=* * *$ & & & & & $* * *$ & & & & & & & & \\
\hline \multirow{2}{*}{$\mathrm{Fe}$} & $\mathrm{R}=\mathrm{NS}$ & NS & -0.288 & NS & NS & NS & NS & -0.333 & NS & & & & & \\
\hline & $\mathrm{P}=\mathrm{NS}$ & & ** & & & & & $* * *$ & & & & & & \\
\hline \multirow{2}{*}{$\mathrm{Zn}$} & $\mathrm{R}=0.230$ & NS & NS & NS & NS & NS & NS & NS & NS & NS & & & & \\
\hline & $\mathrm{P}=$ * & & & & & & & & & & & & & \\
\hline \multirow{2}{*}{ Protein } & $\mathrm{R}=0.539$ & 0.283 & 0.348 & NS & -0.249 & 0.656 & NS & 0.575 & NS & -0.366 & NS & & & \\
\hline & $\mathrm{P}=* * *$ & $* *$ & $* * *$ & & ** & $* * *$ & & $* * *$ & & $* * *$ & & & & \\
\hline \multirow{2}{*}{ Oil } & $\mathrm{R}=-0.342$ & -0.201 & -0.314 & NS & NS & -0.534 & NS & -0.559 & NS & 0.405 & 0.310 & -0.668 & & \\
\hline & $\mathrm{P}=* * *$ & * & ** & & & $* * *$ & & $* * *$ & & $* * *$ & $* *$ & $* * *$ & & \\
\hline \multirow{2}{*}{ Oleic } & $\mathrm{R}=0.486$ & 0.396 & NS & NS & -0.239 & 0.532 & 0.042 & 0.387 & 0.460 & NS & 0.326 & 0.412 & -0.238 & \\
\hline & $\mathrm{P}=* * *$ & $* * *$ & & & * & $* * *$ & * & $* * *$ & $* * *$ & NS & $* * *$ & $* * *$ & * & \\
\hline \multirow{2}{*}{ Linoleic } & $\mathrm{R}=-0.537$ & NS & NS & NS & NS & -0.516 & NS & NS & -0.339 & NS & -0.234 & -0.440 & 0.296 & -0.290 \\
\hline & $\mathrm{P}=* * *$ & & & & & $* * *$ & & & $* * *$ & & * & $* * *$ & $* *$ & $* *$ \\
\hline
\end{tabular}

${ }^{a}$ Nitrogen fertilizer (urea ammonium nitrate) solution (UAN, 32\% N) was applied at rates 44.7 (T1), 67.2 (T2), 89.6 (T3), and 112.0 (T4) kg.ha ${ }^{-1}$, and the rate at $44.7 \mathrm{~kg} \cdot \mathrm{ha}^{-1}$ was considered control as is traditionally recommended in the region. ${ }^{*}$ Significance at $\mathrm{P} \leq 0.05 ;{ }^{* *}$ significance at $\mathrm{P} \leq 0.01 ;{ }^{* *}$ significance at $\mathrm{P}$ $\leq 0.001$.

oil, oleic, and linoleic acids are consistent with variety/genotype selection and $\mathrm{N}$ fertilizer management being important factors in managing seed composition constituents and achieving better seed nutritional qualities. The significant effects of $\mathrm{Y}, \mathrm{Var}$, and $\mathrm{T}$, and their interactions for oil, oleic and linoleic acids, $\mathrm{Mg}$, $\mathrm{B}, \mathrm{Cu}, \mathrm{Fe}$, and $\mathrm{Zn}$ indicate that sesame varieties studied responded differently in 
each year for these nutrients and responded differently to $\mathrm{N}$ application rates. The different responses among varieties studied for accumulating these nutrients in each year could be due to environmental factors that differed in the two years, particularly temperature. Drought is unlikely to be an important factor, because the crop was irrigated in both years. In 2014, the maximum temperatures were $31.39^{\circ} \mathrm{C}, 31.15^{\circ} \mathrm{C}$, and $32.49^{\circ} \mathrm{C}$, and $31.28^{\circ} \mathrm{C}$, respectively in June, July, August, and September; and in 2015 the maximum temperatures were $32.63^{\circ} \mathrm{C}, 34.10^{\circ} \mathrm{C}$, $33.35^{\circ} \mathrm{C}, 33.0^{\circ} \mathrm{C}$, respectively in June, July, August, and September (Figure 5) [46]. It is clear that the 2015 sesame growing season was warmer than the 2014 growing season. High temperatures affect the uptake of nutrients from the soil, and the movement of nutrients from leaves (source) to seed (sink). High temperatures during the growing season, particularly during the crucial seed-filling period, can alter the accumulation of nutrients in seeds, as previously reported in sesame and other species [13] [14] [47] [48] [49] [50].

\subsection{Effects of Increased N Fertilizer on Seed Composition}

The increase of mean values of yield with the increasing of $\mathrm{N}$ fertilizer rate was associated with increased yield, especially at rates $44.7 \mathrm{~kg} \cdot \mathrm{ha}^{-1}, 67.2 \mathrm{~kg} \cdot \mathrm{ha}^{-1}$, and $89.6 \mathrm{~kg} \cdot \mathrm{ha}^{-1}$. Previous research showed that, using nitrogen fertilizer rates $(0,40$ and $\left.80 \mathrm{~kg} \cdot \mathrm{ha}^{-1}\right)$, the rate of $80 \mathrm{~kg} \cdot \mathrm{ha}^{-1}$ gave maximum seed yield $\left(0.79\right.$ tones.ha $\left.{ }^{-1}\right)$.
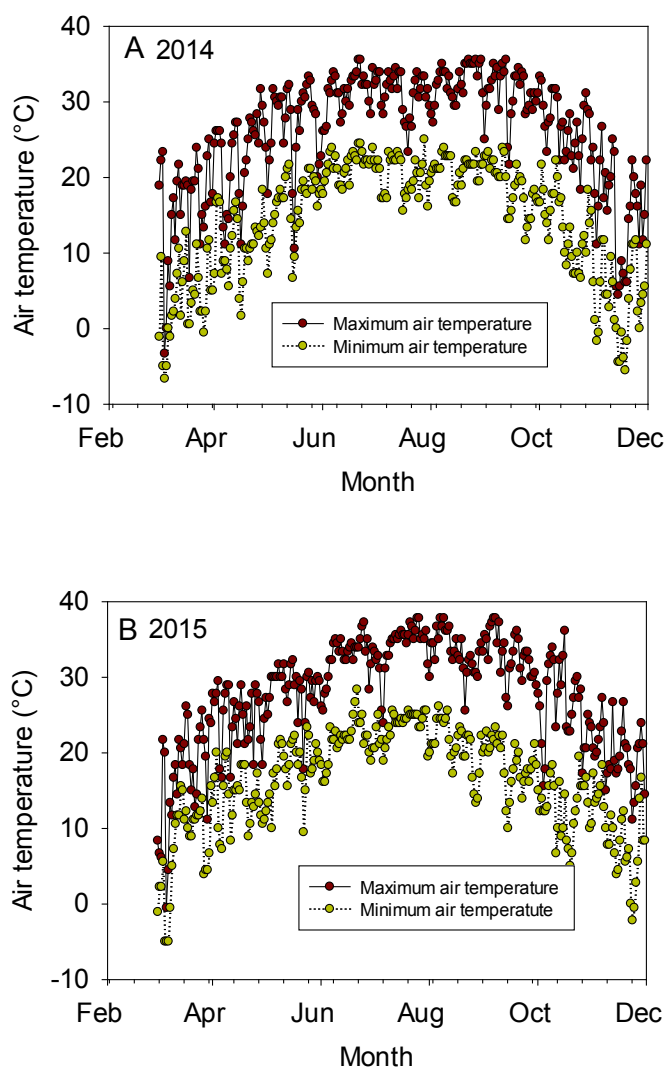

Figure 5. Air temperature $\left({ }^{\circ} \mathrm{C}\right)$ during the growing season in 2014 (A) and 2015 (B). The experiment was conducted in 2014 and 2015 in Stoneville MS. Source: MSUCares (2018). 
Also, it was found in other species including sesame that $\mathrm{N}$ fertilizers resulted in higher yield and yield components [16] [17] [18] [19] [21] [23] [24]. Our research showed that yield increased with the increase of $\mathrm{N}$ rate, although the increases in yield were different among varieties in magnitude due to genetic differences for nutrient use efficiencies. Increased yield associated with $\mathrm{N}$ fertilizer application could be due to increased plant height ( $7 \%$ increases), increased number of capsules per plant (11\% increases), increased number of seeds per capsule (3\% increases) or increased 1000 seed weight (15\% increases) [16]. However, another study reported that increased application of $\mathrm{N}$ fertilizer did not increase plant height, but did increase the number of branches per plant [17]. Our research is in agreement with that of others [16] [17] [18] [19] in that increased $\mathrm{N}$ application was associated with increased seed yield, but it may have a negative impact on yield and yield components at high $\mathrm{N}$ application rates such as $112.1 \mathrm{~kg} \cdot \mathrm{ha}^{-1}$.

\subsection{General Discussion}

The effect of fertilizers, including $\mathrm{N}$ fertilizer application has been studied previously, but the results of these studies are still controversial or not well studied. For example, the effects of nitrogen fertilizer rates $\left(0,40\right.$ and $\left.80 \mathrm{~kg} \cdot \mathrm{ha}^{-1}\right)$ on sesame seed composition showed that the application rate of $80 \mathrm{~kg} \cdot \mathrm{ha}^{-1}$ resulted in the highest oil content (45.88\%) [16]. Other investigators have reported results inconsistent with the observations of others [16]. For example, it was reported that the application of $\mathrm{N}$ fertilizers resulted in a decrease of seed oil contents compared with the control [20]. The effects of $\mathrm{N}$ fertilizer application rates $(0$, 25 , and $50 \mathrm{~kg} \mathrm{~N} \mathrm{ha}^{-1}$ ) was investigated on three sesame cultivars, and found that $\mathrm{N}$ application significantly decreased saturated fatty acids (palmitic and stearic acid), but significantly increased unsaturated fatty acids (oleic and linoleic acid) [51]. It was reported that different $\mathrm{N}$ fertilizer sources led to a high oil and protein content [28]. On the other hand, it was reported that $\mathrm{N}$ application did not change sesame seed oil content [18] [27]. Our results are in partial agreement with those of [26] [28] in that increased $\mathrm{N}$ fertilizer increased oleic acid, protein, minerals, but decreased linoleic acid and oil, and this pattern was shown also when the data was expressed across the two years (Figures 1-4(A-K)). Our results disagreed with those of [18] [27] who reported that the application of $\mathrm{N}$ did not affect oil content, or increased oil content. The increase in seed protein and oleic acid, N, S, and minerals with increased of $\mathrm{N}$ fertilizer application rates could be due to enhanced photosynthesis rates resulting from a greater supply of metabolites in plant tissues [51]. The enhanced supply of metabolites in plant tissues results from abundant $\mathrm{N}$ available due high $\mathrm{N}$ content in the soil and high $\mathrm{N}$ absorption [52]. The increase in seed $\mathrm{N}, \mathrm{S}$, and minerals with $\mathrm{N}$ fertilizer increases could be due to the established inter-relationships between $\mathrm{N}$ and other nutrients and their balance in plant tissues [53] [54] [55].

Inconsistencies between different studies could be the result of genetic differences between the sesame varieties used in the various studies. The uniformity of 
the varieties included in the present study with respect to nutrient handling efficiency was investigated by plotting distributions of seed yield, N, S, K, B, Cu, Fe, $\mathrm{Zn}$, protein, oil, oleic and linoleic acids in sesame seed samples harvested from all field plots included in the two years of the present study. Uniformity is indicated by a single normal probability distribution. While some factors such as yield do give normal distributions, and some nutrient distributions are bimodal (e.g., $\mathrm{Cu}$ ), the distributions of most nutrients are complex, consistent with varietal and genetic differences in the efficiency with which some varieties accumulate more nutrients than others (Figures 6(A-L)).

\subsection{Correlations of N Fertilizer Application Rate with Yield, Seed Composition, and Minerals}

The strong positive correlation of increased $\mathrm{N}$ fertilizer application rates $(\mathrm{T})$
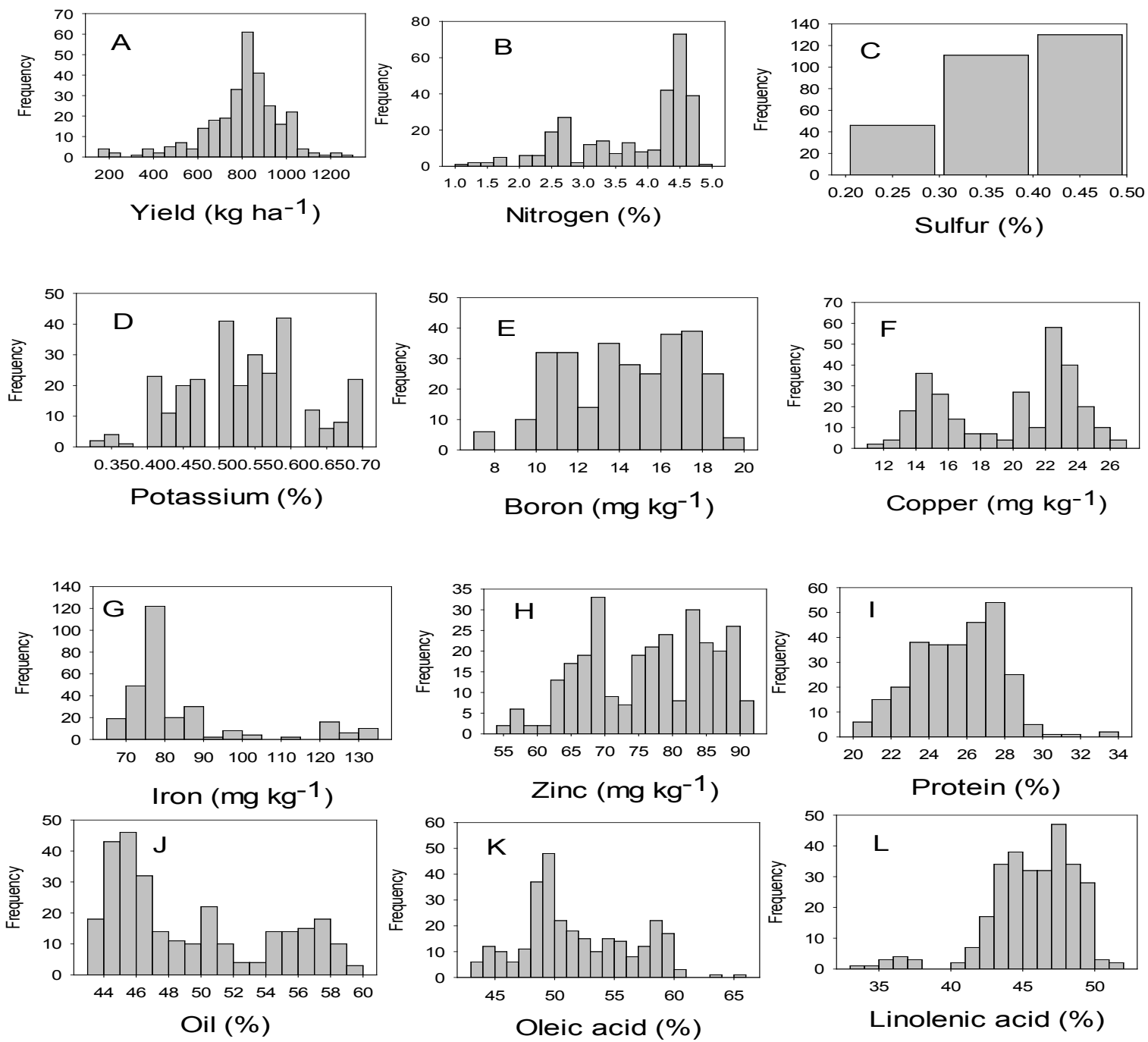

Figure 6. Distributions of sesame seed yields, nutrient content of $\mathrm{N}, \mathrm{S}, \mathrm{K}$, and minerals (B, $\mathrm{Cu}, \mathrm{Fe}$, and $\mathrm{Zn}$ ), and seed composition constituents (protein, oil, oleic and linoleic acids) (A-L) in all field plot samples collected in this study, including all varieties and both years of the study. 
with seed protein, oleic acid, N, B, Cu, and Zn in 2014 and 2015 implies that an increased of $\mathrm{N}$ application rate would result in higher content of these nutrients in sesame seed under Mississippi Delta conditions, thereby increasing seed nutritional qualities. The increase of protein and oleic acid was accompanied by a decrease in oil and linoleic acid, indicating the inherited genetic inverse relationship between protein and oil and between oleic and linoleic acid, and the environmental effects under which the crop grows [49]. These patterns were observed in other studies in sesame and other species. For example, applying $\mathrm{N}$ fertilizer rates of 0,25 , and $50 \mathrm{~kg} \mathrm{~N} \mathrm{ha}^{-1}$ on three sesame cultivars, found that $\mathrm{N}$ application significantly increased unsaturated fatty acids, and oleic acid content exhibited a significant negative correlation with linoleic acid ( $r=-0.79)$ [51]. Similar results were reported by others on sesame [8] and soybean.

\section{Conclusion}

Our research demonstrated that yield can increase with increased $\mathrm{N}$ fertilizer application. However, application of high $\mathrm{N}$ fertilizer rates such as $112.1 \mathrm{~kg} \cdot \mathrm{ha}^{-1}$ may have a negative impact, reducing seed yield. Increased $\mathrm{N}$ fertilizer can increase seed protein and oleic acid and increase the level of some nutrients in sesame seeds, such as $\mathrm{N}, \mathrm{S}, \mathrm{B}, \mathrm{Cu}$, and $\mathrm{Zn}$. The increase of protein and oleic acid is desirable as they contribute to high quality meal and oil stability. However, these increases in protein and oleic acid were accompanied with a reduction in amount of oil and linoleic acid as these constituents are inversely correlated. It appears that the $\mathrm{N}$ fertilizer application rate of $89.9 \mathrm{~kg} \cdot \mathrm{ha}^{-1}$ resulted in an overall higher seed yield and seed nutritional qualities. Further research is needed to understand the genetic mechanisms contributing to the different responses of sesame varieties to increased $\mathrm{N}$ fertilizer. This could be achieved by conducting another field experiment with isogenic lines having similar genetic background, but differing in their $\mathrm{N}$ uptake efficiencies to further understand the genetic, physiological, and environmental responses to varying $\mathrm{N}$ fertilizer applications. This research benefits sesame breeders by allowing them to select varieties that respond well to increased $\mathrm{N}$ fertilizer application to give greater seed nutritional qualities, and it helps growers manage $\mathrm{N}$ fertilizer use.

\section{Acknowledgements}

We thank Sandra Mosley for analyses, Austin Li, Jeremy K. Kotowicz, Terry Johnson, and Austin Hairston for their technical assistance. This work was funded in part by Mississippi State University, Delta Research and Extension Center, Stoneville MS, USA, and also funded by the U.S. Department of Agriculture, Agricultural Research Service Project 6066-21220-012-00D, Department of Agriculture. Mention of trade names or commercial products in this publication is solely for the purpose of providing specific information and does not imply recommendation or endorsement by the United States Department of Agriculture (USDA). USDA is an equal opportunity provider and employer 


\section{Conflicts of Interest}

The authors declare no conflicts of interest regarding the publication of this paper.

\section{References}

[1] Zeven, A. and Zhukovsky, P. (1975) Dictionary of Cultivated Plants and Their Centres of Diversity. Excluding Ornamentals, Forest Trees and Lower Plants. PUDOC, Wageningen.

[2] Hawkes, J. (1983) The Diversity of Crop Plants. Harvard University Press, Cambridge. https://doi.org/10.4159/harvard.9780674183551

[3] Chakraborthy, G.S., Sharma, G. and Kaushik, K.N. (2008) Sesamum indicum: A Review. Journal of Herbal Medicine and Toxicology, 2, 15-19.

[4] Agricultural Marketing Resources Center (2018). https://www.agmrc.org/commodities-products/grains-oilseeds/sesame-profile/

[5] Kiranmayi, S.L., Roja, V., Padmalatha, K., Sivaraj, N. and Sivaramakrishnan, S. (2016) Genetic Diversity Analysis in Sesame (Sesamum indicum) Using Morphological, Biochemical and Molecular Techniques. International Journal of Applied Biology and Pharmaceutical Technology, 7, 95-110.

[6] Erbas, M., Sekerci, H., Gül, S., Furat, S., Yol, E. and Uzun, B. (2009) Changes in Total Antioxidant Capacity of Sesame (Sesamum sp.) by Variety. Asian Journal of Chemistry, 21, 5549-5555.

[7] Arslan, Ç., Uzun, B.U., Ülger, S.C. and İlhan Çağırgan, M.I. (2007) Determination of Oil Content and Fatty Acid Composition of Sesame Mutants Suited for Intensive Management Conditions. Journal of the American Oil Chemists' Society, 84, 917-920. https://doi.org/10.1007/s11746-007-1125-6

[8] Were, B.A., Onkware, A.O., Gudu, S., Welander, M. and Carlsson, A.S. (2006). Seed Oil Content Aand Fatty Acid Composition Iin East African Sesame (Sesamum indicum L.) Accessions Evaluated over 3 Years. Field Crop Research, 97, 254-260. https://doi.org/10.1016/j.fcr.2005.10.009

[9] Mohamed, H.M.A. and Awatif, I.I. (1998) The Use of Sesame Oil Un-Saponifiable Matter as a Natural Antioxidant. Food Chemistry, 62, 269-276. https://doi.org/10.1016/S0308-8146(97)00193-3

[10] Wood, R. (1999) The New Whole Foods Encyclopedia: A Comprehensive Resource for Healthy Eating. Penguin Putnam Inc., New York.

[11] Alpaslan, M., Boydak, E., Hayta, M., Gerçek, S. and Simsek, M. (2001) Effect of Row Space and Irrigation on Seed Composition of Turkish Sesame (Sesamum indicum L.). Journal of the American Oil Chemists' Society, 78, 933-935. https://doi.org/10.1007/s11746-001-0366-0

[12] Hiremath, S.C., Patil, C.G., Patil, K.B. and Nagasampige, M.H. (2007) Genetic Diversity of Seed Lipid Content and Fatty Acid Composition in Some Species of Sesamum L. (Pedaliaceae). African Journal of Biotechnology, 6, 539-543.

[13] Olowe, V.I.O. and Adeoniregun, O.A. (2010) Seed Yield, Yield Attributes and Oil Content of Newly Released Sesame (Sesamum indicum L.) Varieties. Archives of Agronomy and Soil Science, 56, 201-210. https://doi.org/10.1080/03650340903006176

[14] May, W.E., Hume, D.L. and Hale, B.A. (1993) Effects of Agronomic Practices on Free Fatty Acid Levels in the Oil of Ontario-Grown Spring Canola. Canadian Jour- 
nal of Plant Science, 74, 267-274. https://doi.org/10.4141/cjps94-053

[15] Karmaka, S., Lague, C., Agnew, J. and Landry, H. (2007) Integrated Decision Support System (DSS) for Manure Management. Computers and Electrical Engineering, 57, 190-201.

[16] Malik, M.A., Farrukh, S.M., Cheema, M.A. and Ahmed, S. (2003) Influence of Different Nitrogen Levels on Productivity of Sesame (Sesamum indicum L.) under Varying Planting Patterns. International Journal of Agricultural Biology, 4, 490-492.

[17] Ojikpong, T.O. and Olufajo, O.O. (2005) Growth and Yield of (Glycine max L. Merill) as Affected by $\mathrm{N}$ and $\mathrm{P}$ Fertilization. Proceedings of the 39 th Conference of Agricultural Society of Nigeria, Benin, 9-13 October 2005, 187-191.

[18] Kumar, S., Pandey, P. and Maheshwari, D.K. (2009) Reduction in Dose of Chemical Fertilizers and Growth Enhancement of Sesame (Sesamum indicum L.) with Application of Rhizospheric Competent Pseudomonas aeruginosa LES4. European Journal of Soil Biology, 45, 334-340. https://doi.org/10.1016/j.ejsobi.2009.04.002

[19] Jahan, M., Nassiri, M.M., Amiri, M.B. and Ehyayi, H.R. (2013) Radiation Absorption and Use Efficiency of Sesame as Affected by Fertilizers Inoculation in a Low Input Cropping System. Industrial Crops and Products, 43, 606-611. https://doi.org/10.1016/j.indcrop.2012.08.012

[20] Ramakrishnan, A., Sundaramand, A. and Appavoo, K. (1994) Influence of Fertilization on Yield and Components of Sesame (Sesamum indicum L.). The Madras Agriculture Journal, 81, 696-698.

[21] Hossain, M.A., Hamid, A. and Nasreen, S. (2007) Effect of Nitrogen and Phosphorus Fertilizer on N/P Uptake and Yield Performance of Groundnut (Arachis hypogaea L.). Journal of Agricultural Research, 45, 119-127.

[22] Osman, H.E. (1993) Response of Sesame Cultivars to Plant Density and Nitrogen in the Sudan Central Rainlands. Arab Gulf Journal Science Research, 11, 365-376.

[23] Okpara, D.A., Muoneke, C.O. and Ojikpong, T.O. (2007) Effects of Nitrogen and Phosphorus Fertilizer Rates on the Growth and Yield of Sesame (Sesamum indicum L.) in the Southeastern Rain Forest Belt of Nigeria. Nigeria Agricultural Journal, 38, $1-11$.

[24] Olowe, V.I.O. and Busari, L.D. (2000) Response of Sesame (Sesamum indicum L.) to Nitrogen and Phosphorus Applications in Southern Guinea Savanna of Nigeria. Tropical Oil Seeds Journal, 5, 30-37.

[25] Mankar, D.D., Satao, R.N., Solanke, V.M. and Ingole, P.G. (1995) Effect of Nitrogen and Phosphorus on Quality, Uptake and Yield of Sesame. PKV (Puniabrao Krishi Vidyapeeth) Research Journal, 19, 69-70.

[26] Shakeria, E., Modarres-Sanavy, S.A.M., Dehaghi, M.A., Tabatabaei, S.A. and Moradi-Ghahderijani, M. (2015) Improvement of Yield, Yield Components and Oil Quality in Sesame (Sesamum indicum L.) by N-Fixing Bacteria Fertilizers and Urea. Archives of Agricultural Soil Sciences, 62, 547-560.

[27] El-Habbasha, S.F., Abd El Salam, M.S. and Kabesh, M.O. (2007) Response of Two Sesame Varieties (Sesamum indicum L.) to Partial Replacement of Chemical Fertilizer by Bio-Organic Fertilizers. Research Journal of Agriculture and Biological Sciences, 3, 563-571.

[28] Khaled, A., Shaban, G., Mona, C. and Khalil, Z.M. (2012) Effect of Soil Amendments on Soil Fertility and Sesame Crop Productivity under Newly Reclaimed Soil Conditions. Journal of Applied Sciences Research, 8, 1568-1575.

[29] Shilpi, S., Nuruzzaman, M.D., Akhter, F., Islam, M.N. and Sutradher, G.N.C. (2014) 
Response of Nitrogen and Sulfur on the Oil Content of Sesame and Nutrient Status of Soil. International Journal of Bio-Resource and Stress Management, 5, 41-46. https://doi.org/10.5958/j.0976-4038.5.1.007

[30] Bellaloui, N., Smith, J.R., Gillen, A.M. and Ray, J.D. (2011) Effects of Maturity, Genotypic Background, and Temperature on Seed Mineral Composition in Nearisogenic Soybean Lines in the Early Soybean Production System. Crop Science, 51, 1161-1171. https://doi.org/10.2135/cropsci2010.04.0187

[31] Bellaloui, N., Mengistu, A., Walker, E.R. and Young, L.D. (2014) Soybean Seed Composition as Affected by Seeding Rates and Row Spacing. Crop Science, 54, 1782-1795. https://doi.org/10.2135/cropsci2013.07.0463

[32] Dumas, J.B.A. (1831) Procedes de l'analyse organic. Annales de Chimie et de Physique, 247, 198-213.

[33] Holmes, F.L. (1963) Elementary Analysis and the Origins of Physiological Chemistry. ISIS (A Journal of the History of Science Society), 54, 50-81. https://doi.org/10.1086/349664

[34] Childs, C.E. and Henner, E.B. (1970) A Direct Comparison of the Pregl, Dumas, Perkin-Elmer, and Hewlett-Packard (F\&M) Carbon-Hydrogen-Nitrogen Procedures. Microchemical Journal, 15, 590-597. https://doi.org/10.1016/0026-265X(70)90102-5

[35] Lohse, G. (1982) Microanalytical Azomethine-H Method for Boron Determination in Plant Tissue. Communications in Soil Science and Plant Analysis, 13, 127-134. https://doi.org/10.1080/00103628209367251

[36] Dordas, C., Apostolides, G. and Goundra, O. (2007) Boron Application Affects Seed Yield and Seed Quality of Sugarbeets. Journal of Agricultural Science, 145, 377-384. https://doi.org/10.1017/S0021859607006879

[37] John, M.K., Chuah, H.H. and Neufeld, J.H. (1975) Application of Improved Azomethine-H Method to the Determination of Boron in Soils and Plants. Analytical Letters, 8, 559-568. https://doi.org/10.1080/00032717508058240

[38] Bandemer, S.L. and Schaible, P.J. (1944) Determination of Iron. A Study of the Ophenanthroline Method. Industrial and Engineering Chemistry Analytical Edition, 16, 317-319. https://doi.org/10.1021/i560129a013

[39] Loeppert, R.L. and Inskeep, W.P. (1996) Colorimetric Determination of Ferrous Iron and Ferric Iron by the 1,10-Phenanthroline Method. In: Bigham, J.M., Ed., Methods of Soil Analysis: Part 3, Chemical Methods, SSSA, Madison, 659-661.

[40] Cavell, A.J. (1955) The Colorimetric Determination of Phosphorus in Plant Materials. Journal of the Science of Food and Agriculture, 6, 479-480. https://doi.org/10.1002/jsfa.2740060814

[41] AOAC (Association of Official Analytical Chemists) (1990) Method 988.05. In: Helrich, K., Ed., Official Methods of Analysis, 15th Edition, Elsevier Science Publishing, Arlington, 70.

[42] Lynch, J.M. and Barbano, D.M. (1999) Kjeldahl Nitrogen Analysis as a Reference Method for Protein Determination in Dairy Products. Journal of AOAC International, 82, 1389-1398.

[43] Williams, P., Sobering, D. and Antoniszyn, J. (1998) Protein Testing Methods. In: Fowler, D.B., Geddes, W.E., Johnston, A.M. and Preston, K.R., Eds., Wheat Protein Production and Marketing, University of Saskatchewan Extension Press, Saskatoon, 37-47.

[44] AOAC (Association of Official Analytical Chemists) (1990) Method 920.39. In: He- 
lrich, K., Ed., Official Methods of Analysis, 15th Edition, Elsevier Science Publishing, Arlington, 71.

[45] SAS Institute (2002-2010) SAS. SAS Institute, Cary.

[46] Mississippi State University Extension, Delta Agriculture Weather Center (2018) Mississippi. http://deltaweather.extension.msstate.edu/weather-station-result/

[47] Piper, E.L. and Boote, K.J. (1999) Temperature and Cultivar Effects of Soybean Seed Oil and Protein Concentration. Journal of American Oil Chemists' Society, 76, 1233-1241. https://doi.org/10.1007/s11746-999-0099-y

[48] Dardanelli, J.L., Balzarini, M., Martinez, M.J., Cuniberti, M., Resnik, S., Ramunda, S.F., Herrero, R. and Baigorri, H. (2006) Soybean Maturity Groups, Environments, and Their Interaction Define Mega-Environments for Seed Composition in Argentina. Crop Science, 46, 1939-1947. https://doi.org/10.2135/cropsci2005.12-0480

[49] Bellaloui, N., Smith, J.R., Ray, J.D. and Gillen, A.M. (2009) Effect of Maturity on Seed Composition in the Early Soybean Production System as Measured on Near-Isogenic Soybean Lines. Crop Science, 49, 608-620. https://doi.org/10.2135/cropsci2008.04.0192

[50] Bellaloui, N., Ebelhar, M.W., Gillen, A.M., Fisher, D.K., Abbas, H.K., Mengistu, A., Reddy, K.N. and Paris, R.L. (2011b) Soybean Seed Protein, Oil, and Fatty Acids Are Altered by $\mathrm{S}$ and $\mathrm{S}+\mathrm{N}$ Fertilizer under Irrigated and Non-Irrigated Environments. Agriculture Sciences, 2, 465-476. https://doi.org/10.4236/as.2011.24060

[51] Akbari, P., Ghalavand, A., Modares, S.A.M, AghaAlikhani, M. and Shoghi, K.S. (2011) Comparison of Different Nutritional Levels and the Effect of Plant Growth Promoting Rhizobacteria (PGPR) on the Grain Yield and Quality of Sunflower. Australian Journal of Crop Science, 5, 1570-1576.

[52] Dordas, C.A. and Sioulas, C. (2008) Safflower Yield, Chlorophyll Content, Photosynthesis, and Water Use Efficiency Response to Nitrogen Fertilization under Rainfed Conditions. Industrial Crops and Products, 27, 75-85. https://doi.org/10.1016/j.indcrop.2007.07.020

[53] Mengel, K. and Kirkby, E.A. (1982) Principles of Plant Nutrition. International Potash Institute, Worblaufen Bern.

[54] Marschner, H. (1995) Mineral Nutrition of Higher Plants. Academic Press, London.

[55] Bellaloui, N., Bruns, H.A., Abbas, H.K., Mengistu, A., Fisher, D.K. and Reddy, K.N. (2015) Effects of Row-Type, Row-Spacing, Seeding Rate, Soil-Type, and Cultivar Differences on Soybean Seed Nutrition under US Mississippi Delta Conditions. PLoS ONE, 10, e0129913. https://doi.org/10.1371/journal.pone.0129913 